\title{
Formulation of Effective Regulations to Protect Financial Consumers from the Sale of High-risk Financial Products*
}

\author{
Sehoon Kwon, Associate Professor, Sangmyung University \\ Juil Ban**, Associate Professor, Sangmyung University
}

\begin{abstract}
$<$ Abstract $>$
The DLF, Lime fund and Optimus fund scandals highlight the unethical management and sales behavior of financial companies as well as consumers' lowered trust in them; this has raised awareness regarding high-risk financial products and the need for financial consumer protection in Korea. Financial authorities have devised various measures to prevent the recurrence of scandals. Examining the current state of high-risk financial product sales and the newly introduced regulatory measures, this study investigates whether there exists any lack in the financial consumer protection and regulatory measures. If financial companies play a responsible role in protecting financial consumers while manufacturing and selling risky and complex financial products and providing innovative investment opportunities and profit structures that cannot be found in the existing financial products, financial consumers' trust may be restored in them. High-risk financial products should not be the means of exploiting financial consumers who lack financial literacy, but rather to enhance the dynamics of the capital market through efficient capital intermediation and risk diversification.
\end{abstract}

Keywords: Financial Consumer; Policy and Regulation; High-risk Financial Products; Derivative Embedded Security; Private Placement Fund

JEL Classification: G10, G11, G18

* This study is based on the paper presented at the policy symposium hosted by Korean Securities Association and Korea Capital Market Institute on June 9, 2021. We would like to thank Professor Yongmin Joe of Korea University and Professor Heejoon Ahn of Sungkyunkwan University for presiding over the symposium and Managing Director Junghoon Kim of Samsung Asset Management, Professor Kibeom Binh of Myongji University, Dr. Minseop Yun of Korea Financial Consumers Protection Foundation, Managing Director Yooihn Chung of Mirae Asset Securities, and Director Seongki Hong of Financial Services Commission for conducting a discussion on the paper. This research received a Research Grant from Sangmyung University in 2021.

** Corresponding Author. Address: College of Business and Economics, Sangmyung University, 20 Honggimun 2-gil, Jongno-gu, Seoul, Korea 03016; E-mail: ban9415@smu.ac.kr; Tel: +82-2-781-7586; Fax: +82-2-2287-0059.

Received: July 27, 2021; Accepted: August 10, 2021 


\title{
고위험 금융상품 판매현황 및 금융소비자 보호를 위한 합리적 규제 ${ }^{*}$
}

\author{
권 세 훈 (상명대학교 부교수) \\ 반 주 일 (상명대학교 부교수)**
}

\begin{abstract}
DLF(Derivative Linked Fund) 사태, 라임.옵티머스 사태는 금융기관의 부도덕한 운용행태 및 판매 행태를 부각하면서 금융기관에 대한 신뢰를 추락시켰고, 고위험 금융상품에 대한 경각심을 유발하면서, 금융소비자 보호의 필요성을 우리 사회에 각인시키는 계기가 되었다. 금융당국에서는 사태의 재발을 막기 위해 다양한 개선책들을 내놓았다. 본 연구는 고위험 금융상품 판매현황에 대해 살펴본 후, 당국의 규제방안에도 불구하고 여전히 미흡한 점이 무엇인지 논의하고 합리적 규제에 관한 의견을 제시하였다. 금융기관이 위험하고 복잡한 금융상품을 제조하고 판매함에 있어 금융소비자 보호를 위한 책임있는 역할을 수행하면서, 지속적인 혁신을 통해 기존의 상품으로는 달성 불가능한 투자기회와 수익구조를 제공하게 된다면, 금융소비자로부터 신뢰를 회복할 수 있을 것이다. 고위험 금융상품이 금융이해력이 부족한 금융소비자를 착취하는 수단이 아니라, 효율적인 자본중개와 위험분산 기능을 수행하며 자본시장의 역동성을 제고하는 수단이 되기를 기대한다.
\end{abstract}

핵심 단어 : 금융소비자, 규제, 고위험 금융상품, 파생결합증권, 사모펀드

JEL 분류기호: G10, G11, G18

* 본 연구는 2021년 6월 9일에 개최된 한국증권학회·자본시장연구원 공동 정책심포지엄에서 발표된 내용을 논문으로 정리한 것입니다. 진행을 맡아주신 고려대학교 조용민 교수님, 사회를 담당 하신 성균관대학교 안희준 교수님과 토론에 참여해 주신 삼성자산운용 김정훈 본부장님, 명지 대학교 빈기범 교수님, 한국금융소비자보호재단 윤민섭 박사님, 미래에셋증권 정유인 본부장님, 금융위원회 홍성기 과장님께 감사드립니다. 본 연구는 2021년도 상명대학교 교내연구비를 지원받아 수행하였음.

** 연락담당 저자. 주소: 서울시 종로구 홍지문 2길 20 상명대학교 경영경제대학 글로벌경영학과, 03016; E-mail: ban9415@smu.ac.kr; Tel: 02-781-7586; Fax: 02-2287-0059. 


\section{1. 서론}

2019년과 2020년에 발생한 DLF(Derivative Linked Fund) 사태 ${ }^{1)}$, 라임 사태 ${ }^{2)}$, 옵티머스 사태 ${ }^{3)}$ 는 광범위한 금융소비자 피해를 양산하면서 언론을 뜨겁게 달구었다. 안전성을 강조 하면서 인기리에 판매되었던 독일, 영국, 미국 주요 해외금리 연계 DLF는 210 개가 설정 되어 3,243명의 투자자에게 7,950억 원이라는 자금을 끌어 모았는데 확정 또는 예상 손실률이 $50 \%$ 를 초과하는 대규모 손실사태를 초래하였다. 투자자의 $92.6 \%$ 는 개인 일반투자자였으며, 안정적인 자산운용이 중요시되는 60대 70대 고령투자자 비중이 $69.7 \%$ 에 달하였다. 금융 기관은 금융소비자 보호보다는 수수료 수익에 치중하여 설명의무, 투자자성향 파악의무, 고령투자자 보호절차 등을 위반하여 불완전판매 문제가 부각되었다. 라임자산운용은 전체 수탁고가 4.5조 원에 달할 정도로 사모전문운용사로서 급성장하였는데, 2019년 말 기준으로 173 개의 펀드에서 총 1 조 6,679 억 원의 환매연기사태가 발생하였다. 유동성 위험을 고려 하지 않은 펀드 만기구조, 펀드 간 손실전가, 인위적인 기준가 산정, 직무관련 정보를 이용한 임직원의 사적이익 취득, 주가조작 범죄 가담 등이 문제가 되었다. 옵티머스자산운용은 안정적인 자산에 투자하는 것처럼 제안서를 거짓으로 꾸민 후 46개 펀드에서 5,151억 원의 투자자금을 유치하여 실제로는 비상장기업의 사모사채를 매입하고, 해당기업은 부동산 개발 사업, 비상장주식, $\mathrm{PF}$ 사업 등 위험자산에 투자하였고, 2020년 7월 기준으로 22개 펀드에서 2,400 억 원의 환매연기사태가 발생하였다. 라임과 옵티머스의 주요 판매사였던 시중은행과 주요증권사에서는 이러한 위법·불건전 운용행위에도 불구하고 별다른 검증절차 없이 펀드를 지속적으로 판매했다는 점 또한 큰 문제였다.

DLF 사태, 라임·옵티머스 사태는 결과적으로 금융기관의 부도덕한 운용행태 및 판매행태를 부각하면서 금융기관에 대한 신뢰를 추락시켰고, 고위험 금융상품에 대한 경각심을 유발 하면서, 금융소비자 보호의 필요성을 우리 사회에 각인시키는 계기가 되었다. 금융당국에서는 사태의 재발을 막기 위해 '고위험 금융상품 투자자 보호 강화를 위한 종합 개선방안', '고난도 금융투자상품 제조 및 판매에 관한 표준영업행위준칙', ‘사모펀드 현황 평가 및 제도개선 방안', '파생결합증권시장 건전화 방안' 등 다양한 개선책들을 내놓았다. 본 연구는 고위험 금융상품 판매현황에 대해 살펴본 후, 금융당국의 규제방안에도 불구하고 여전히 미흡한 점이 무엇인지 논의하고 합리적 규제를 위한 제언들을 제시하는 것을 목표로 하였다.

금융기관이 위험하고 복잡한 금융상품을 제조하고 판매함에 있어 금융소비자 보호를 위한 책임있는 역할을 수행하면서, 지속적인 혁신을 통해 기존의 상품으로는 달성 불가능한 투자

1) 사태의 배경 및 내용, 진행경과에 대해서는 Financial Supervisory Service(2019a)를 참조하였음.

2) 사태의 배경 및 내용, 진행경과에 대해서는 Financial Supervisory Service(2020a)를 참조하였음.

3) 사태의 배경 및 내용, 진행경과에 대해서는 Financial Supervisory Service(2020b)를 참조하였음. 
Effective Regulations to the Sale of High-risk Financial Products

기회와 수익구조를 제공하게 된다면, 금융소비자로부터 신뢰를 회복할 수 있을 것이다. 고위험 금융상품이 금융이해력이 부족한 금융소비자를 착취하는 수단이 아니라, 효율적인 자본중개와 위험분산 기능을 수행하며 자본시장의 역동성을 제고하는 수단이 되기를 기대 한다.

이 연구의 이후 구성은 다음과 같다. 제 2장에서는 고위험, 복잡성, 고난도, 파생결합증권 등 주요 용어를 정리하고 금융소비자보호를 바라보는 관점을 개관한다. 제 3 장에서는 금융 투자협회 종합통계서비스(freesis.kofia.or.kr)의 통계자료에 기반하여 고위험 금융상품 판매 현황에 대해 살펴보고자 한다. 제 4장에서는 금융당국이 내놓은 고위험 금융상품 관련 제도 개선방안의 주요내용을 요약한다. 제 5장에서는 금융당국의 많은 규제책에도 불구하고 여전히 미흡한 점을 논의하고 합리적 규제를 위해 필요한 사항을 제언한다. 끝으로 제 6장에서는 전체내용을 정리하면서 논문을 마무리하고자 한다.

\section{2. 용어정리 및 선행연구}

\section{1 금융상품에서의 고위험}

실무적으로 고위험 금융상품을 정의할 때 <표 1 과 같이 다양한 기준들이 사용되고 있다. 공모펀드 시장에서는 오래 전부터 투자대상 기준을 사용하여 주식, 투기등급채권, 파생상품 등을 고위험 자산으로 분류하여 오다가, 2016년부터 변동성 기준을 추가하여 3년이 경과한 펀드에 대해서는 주간 수익률의 연환산 표준편차를 계산하여 위험등급을 분류하고 있다. 금융소비자에게는 상승과 하락을 모두 반영하는 변동성보다는 원금손실 가능성에 초점을 맞추는 손실위험 기준이 좀 더 직관적인 기준이라고 할 수 있으며, 금융투자업계에서는 업무관행상 최대 원금손실 비율 $20 \%$ 를 고위험상품 분류기준으로 활용하고 있다. 그리고 최근에는 '금융소비자가 이해할 수 있는가'라는 복잡성 기준이 부각되고 있으며, 기초자산의 특성, 가격결정방식, 손익구조, 위험 등을 이해하기 어려운 경우 고위험 금융상품으로 분류 하고 있다.

또한 금융회사에서는 금융소비자에게 판매하는 금융투자상품에 대해서 자체적인 위험 분류등급을 산출하고 있다. <그림 1>은 신한금융투자 홈페이지에서 발췌한 금융투자상품 위험도 분류 예시를 나타낸다. 이 분류는 모든 금융투자상품을 5 개의 등급으로 구분하여 고객 투자성향과의 적합성을 매칭해 준다. 초고위험(1등급) 상품 범주에는, 1 2등급 펀드, 투기등급 채권, 원금 비보장형 ELS(Equity Linked Security)/DLS(Derivative Linked Security), ELW(Equity Linked Warrant), ETN(Exchange Traded Note) 등이 포함되며, 신탁의 경우에는 편입자산이 초고위험 상품일 때 해당 신탁상품 또한 초고위험으로 분류 하고 있다. 
〈표 1〉 금융상품에서의 고위험 기준

실무적으로 고위험 금융상품을 정의할 때 사용되는 다양한 기준과 사용 예시를 나타낸다.

\begin{tabular}{|c|c|c|}
\hline 구분 & 기준 & 예시 \\
\hline 투자대상 & $\begin{array}{l}\text { - 고위험: } \\
\text { 주식, 투기등급채권, 파생상품 등 } \\
\text { - 중위험: } \\
\text { BBB-급 이상 채권, 담보부 대출 등 } \\
\text { - 저위험: } \\
\text { 국공채, } \mathrm{A} \text {-급 이상 채권, 현금성자산 등 }\end{array}$ & $\begin{array}{l}\text { - 펀드 최초 설정시 투자대상 자산 및 } \\
\text { 비중과 운용계획 등을 고려하여 운용 } \\
\text { 사가 부여하는 등급체계 }\end{array}$ \\
\hline 변동성 & - 수익률의 표준편차 & $\begin{array}{l}\text { - 펀드 설정 후 } 3 \text { 년 경과시 주간수익률의 } \\
\text { 연환산 표준편차 기준으로 부여하는 등급 } \\
\text { 체계 }\end{array}$ \\
\hline 레버리지 & $\begin{array}{l}\text { - 금전차입 } \\
\text { - 파생상품 위험평가액 }\end{array}$ & $\begin{array}{l}\text { - 금전차입이 허용되는 경우 } \\
\text { - 파생상품 위험평가액이 } 100 \% \text { 를 초과하는 } \\
\text { 경우 }\end{array}$ \\
\hline 실위험 & - 원금손실 가능성 & - 최대손실률 $20 \%$ 이상인 경우 \\
\hline 복잡성 & - 투자자의 이해 가능성 & $\begin{array}{l}\text { - 기초자산의 특성, 가격결정방식, 손익구조, } \\
\text { 위험을 이해하기 어려운 경우 } \\
\end{array}$ \\
\hline 투명성 & $\begin{array}{l}\text { - 인허가, 투자자공시, 자산가치평가, } \\
\text { 감독, 규제 등 } \\
\text { - 불건전성, 위법성 등 }\end{array}$ & $\begin{array}{l}\text { - 사모펀드가 공모펀드보다 위험한 것으로 } \\
\text { 간주 } \\
\text { - 불건전 운용, 불완전 판매, 사기, 금융 } \\
\text { 범죄 등 }\end{array}$ \\
\hline 0 & $\begin{array}{l}\text { - 매매가 어려운 비시장성 자산 투자 } \\
\text { 여부 } \\
\text { - 장기투자가 요구되는 투자안 }\end{array}$ & $\begin{array}{l}\text { - 펀드만기와 보유자산 만기의 불일치 } \\
\text { - 폐쇄형 구조 }\end{array}$ \\
\hline
\end{tabular}

〈그림 1〉금융투자상품 위험도 분류표 예시

신한금융투자 홈페이지(https://www.shinhaninvest.com)에서 발췌한 금융투자상품 위험도 분류표이다.

\begin{tabular}{|c|c|c|c|c|c|c|c|}
\hline \multicolumn{2}{|c|}{ 금용투자상품 위험등급 } & \multicolumn{2}{|c|}{ 초고위혐(1동급) } & 고위혐(2동급) & 중위혐(3등급) & 저위험(4등급) & 초저위험(5등급) \\
\hline \multicolumn{2}{|c|}{ 고객 투따성향 } & \multicolumn{2}{|c|}{ 공격투자형(1등급) } & 적극투자형(2등급) & 위험중립형(3등급) & 안정주구형(4등급) & 안정형(5등급) \\
\hline \multicolumn{2}{|c|}{$\begin{array}{l}\text { 펀드 } \\
\text { (집합투자증권) }\end{array}$} & \begin{tabular}{|c|} 
매우논은위험 \\
(1등급)
\end{tabular} & $\begin{array}{l}\text { 높음위험 } \\
\text { (2등급) }\end{array}$ & $\begin{array}{c}\text { 다소놈응위험 } \\
\text { (3등급) }\end{array}$ & $\begin{array}{l}\text { 보통위험 } \\
\text { (4등급) }\end{array}$ & $\begin{array}{l}\text { 낮은위험 } \\
\text { (5등급) }\end{array}$ & $\begin{array}{c}\text { 매우낮은위험 } \\
\text { (6등급) }\end{array}$ \\
\hline \multirow{3}{*}{ 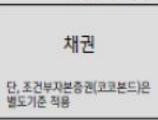 } & 국내 & \multicolumn{2}{|c|}{ 민평사에서 평가 안되는 재권 } & $\mathrm{BB}+$ 이하 재권 & 회사재(BBB+ BBB-) & $\begin{array}{l}\text { 특수채, 금융채 } \\
\text { 회사채(A-이상) } \\
\end{array}$ & $\begin{array}{l}\text { 국고채, 통안채 } \\
\text { 지방채, 보증채 }\end{array}$ \\
\hline & & \multicolumn{2}{|c|}{$\mathrm{BB}+$ 이하 } & $\mathrm{BBB}+\sim \mathrm{BBB}-$ & $A+\sim A^{-}$ & AAAt $\sim A A-$ & \\
\hline & 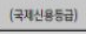 & \multicolumn{4}{|c|}{ 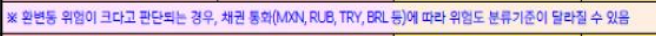 } & \multicolumn{2}{|c|}{ 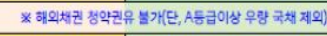 } \\
\hline \multicolumn{2}{|l|}{$C P$} & \multicolumn{3}{|c|}{ 신용등급이 없거나 B이하 } & A3- $\mathrm{A3}+$ & $\mathrm{A} 1_{1+\sim \mathrm{A} 2-}$ & \\
\hline \multirow{2}{*}{ 전자단기사재 } & 원화 & & & & A3- $\mathrm{A3}+$ & $\mathrm{A} 1+\sim \mathrm{A} 2-$ & \\
\hline & 외화 & & & A3- A3+ & $\mathrm{A} 1+\sim \mathrm{A} 2^{-}-$ & & \\
\hline \multicolumn{2}{|l|}{$\mathrm{RP}$} & & & & & 외화RP & 원화RP \\
\hline \multicolumn{2}{|l|}{ CMA } & & & & & & RP형, MMF형, MMW형 \\
\hline \multirow{3}{*}{ 파생결합증권 } & ELS/DLS & \multicolumn{3}{|c|}{ 원금 비보장힝 } & 원금 부분지급행 & & \\
\hline & ELW & \multicolumn{2}{|c|}{ ELW } & & & & \\
\hline & ETN & \multirow{2}{*}{\multicolumn{2}{|c|}{ ETN }} & & & & \\
\hline 파생결합사채 & ELB/DLB & & & & & 원금 지급형 & \\
\hline \multirow[b]{2}{*}{ 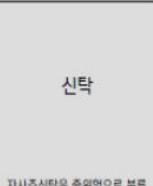 } & 주식형 & $\begin{array}{l}\text { 해외주식, 초 } \\
\text { 당사 종목벨션 } \\
\text { 국내주식, 파수 }\end{array}$ & $\begin{array}{l}\text { 귀험 국내주식, } \\
\text { 8등급 D이하 } \\
\text { 쌍풍에 투자 }\end{array}$ & 고위험 국내주식에 투자 & & & \\
\hline & $\begin{array}{l}\text { 채권형 } \\
\text { CP형 } \\
\text { ELS/DLS형 } \\
\text { 펀드영 } \\
\text { 기타자산형 }\end{array}$ & \multicolumn{5}{|c|}{$\begin{array}{l}\text { 상품 유형별 편입자산(금융투자상품)의 위혐도 분류기준에 따름 } \\
\text { (ETF형 상품은 펀드형 상품의 위험도 분류기준에 따름) }\end{array}$} & \\
\hline
\end{tabular}




\section{2 파생결합증권 명칭 분류}

자본시장법 제 4 조 (1)항에 따르면, 파생결합증권은 기초자산의 가격·이자율·지표·단위 또는 이를 기초로 하는 지수 등의 변동과 연계하여 미리 정하여진 방법에 따라 지급하거나 회수 하는 금전 등이 결정되는 권리가 표시된 것으로 정의된다. ${ }^{4)}$ <표 2>는 다양한 파생결합증권 간에 어떤 차이점이 있는지 정리하였다. 실무적으로 파생결합증권은 크게 비상장 상품인 ELS 및 DLS, 상장 상품인 ELW 및 ETN으로 분류된다. ELS와 DLS를 구분하는 기준은 기초 자산이 주가 또는 주가지수인지, 이외의 기타지수인지 여부이다. 또한 원금보장이 되는 경우에 한하여는 ELB(Equity Linked Bond) 및 DLB(Derivative Linked Bond)라는 명칭이, 펀드 형태로 판매되는 경우 ELF(Equity Linked Fund) 및 DLF(Derivative Linked Fund), 신탁 형태로 판매되는 경우 ELT(Equity Linked Trust) 및 DLT(Derivative Linked Trust)라는 명칭이 별도로 사용된다. 즉, 주요한 몸통이 되는 상품은 ELS 및 DLS이며 원금보장 여부 및 판매형태에 따라 다양한 명칭으로 불리고 있는 것이다. 한편, 현행 자본시장법 시행령에서는 파생결합증권을 고난도금융상품에 포함시키되 거래소 상장 상품은 제외시키고 있다. 거래소 에서 상장되어 거래되는 $\mathrm{ELW}$ 및 $\mathrm{ETN}$ 은 가격이 투명하게 공개되며, 유동성도 높고, 능동 적인 금융소비자가 직접 거래하도록 설계된 상품이기 때문에 비상장 상품과 차별을 둔 것 으로 판단된다.

〈표 2〉파생결합증권 명칭 분류 주요 파생결합증권에 대해 유형별로 그 특징을 정리하였다.

\begin{tabular}{|c|c|c|c|c|}
\hline 시장구분 & 기초자산 & 상품약칭 & 판매형태 & 정식명칭 및 특징 \\
\hline \multirow{8}{*}{ 비상장 } & \multirow{4}{*}{$\begin{array}{l}\text { 주가, } \\
\text { 주가지수 }\end{array}$} & ELS & 증권 & $\begin{array}{l}\text { - Equity Linked Security } \\
\text { - 주가 또는 주가지수 가격변동에 연계 }\end{array}$ \\
\hline & & ELB & 증권 & $\begin{array}{l}\text { - Equity Linked Bond } \\
\text { - 원금이 보장되는 ELS }\end{array}$ \\
\hline & & ELF & 펀드 & $\begin{array}{l}\text { - Equity Linked Fund } \\
\text { - ELS를 포트폴리오로 편입한 펀드 }\end{array}$ \\
\hline & & ELT & 신탁 & $\begin{array}{l}\text { - Equity Linked Trust } \\
\text { - 신탁상품 형태로 판매되는 ELS }\end{array}$ \\
\hline & \multirow{4}{*}{$\begin{array}{l}\text { 금리, } \\
\text { 통화, } \\
\text { 상품, } \\
\text { 신용위험 } \\
\text { 등 }\end{array}$} & DLS & 증권 & $\begin{array}{l}\text { - Derivative Linked Security } \\
\text { - 비주식 지수의 가격변동에 연계 }\end{array}$ \\
\hline & & DLB & 증권 & $\begin{array}{l}\text { - Derivative Linked Bond } \\
\text { - 원금이 보장되는 DLS }\end{array}$ \\
\hline & & DLF & 펀드 & $\begin{array}{l}\text { - Derivative Linked Fund } \\
\text { - DLS를 포트폴리오로 편입한 펀드 }\end{array}$ \\
\hline & & DLT & 신탁 & $\begin{array}{l}\text { - Derivative Linked Trust } \\
\text { - 신탁상품 형태로 판매되는 DLS }\end{array}$ \\
\hline
\end{tabular}

4) 파생결합증권의 법적 개념, 주요 사례, 발전과정 등에 대한 소개는 Kwon(2019)를 참조할 것. 
한국증권학회지 제 51 권 1호 (2022)

〈표 2〉파생결합증권 명칭 분류(계속)

\begin{tabular}{|c|c|c|c|c|}
\hline 시장구분 & 기초자산 & 상품약칭 & 판매형태 & 정식명칭 및 특징 \\
\hline \multirow[t]{2}{*}{ 상장 } & $\begin{array}{l}\text { 주가, } \\
\text { 주가지수 }\end{array}$ & ELW & 증권 & $\begin{array}{l}\text { - Equity Linked Warrant } \\
\text { - 옷션의 수익구조(미래에 사거나 팔 수 있는 } \\
\text { 권리), 주가 또는 주가지수 가격변동에 연계 }\end{array}$ \\
\hline & $\begin{array}{l}\text { 비주식 } \\
\text { 지수 }\end{array}$ & ETN & 증권 & $\begin{array}{l}\text { - Exchange Traded Note } \\
\text { - 기초자산 가격변동에 연계 }\end{array}$ \\
\hline
\end{tabular}

\section{3 복잡성}

Financial Industry Regulatory Authority(2012)는 금융상품의 복잡성(complexity)에 대하여 다음과 같이 설명하고 있다. 먼저, 투자손실 가능성을 줄여보기 위해서 복잡성이 생겨난 것이라 하더라도, 금융상품의 복잡성은 투자의사결정 과정에서 고려해야 할 새로운 차원(dimension)이기 때문에, 특정 금융상품이 복잡하다는 것은 금융소비자에게 부가적인 위험(additional risk)이 된다는 것이다. 또한, 금융회사와 금융소비자들이 이해하기 어렵기 때문에 부적합한 권유나 판매행위가 발생할 수 있다는 것이다.

Koh et al.(2015)는 기존의 위험 차원에 복잡성 차원을 추가하여 금융상품을 2 차원적으로 분류하는 방법을 시도하고 있다. 〈그림 2>는 해당 문헌의 Table 1에서 발췌한 것이다. 좌표 $(1,1)$ 에는 위험이 가장 낮으면서, 복잡성도 가장 낮은 상품으로 은행예금(fixed deposits)이 위치하고 있다. 좌표 $(1,5)$ 에는 위험은 가장 높으면서, 복잡성은 가장 낮은 상품으로 고위험 주식(high-risk stocks)이 위치한다. 좌표 $(5,5)$ 에는 위험이 가장 높으면서, 복잡성도 가장 높은 상품으로 구조화상품(complex structured products)이 위치한다. 흥미롭게도 좌표 $(5,1)$ 에는 위험은 가장 낮으면서, 복잡성은 가장 높은 상품이 존재하지 않는다. 복잡성이 위험을 줄여보려는 의도에서 태동했다고 가정한다면 위험이 낮은 상품의 경우 위험의 성격 이나 구조를 변화시킬 필요성이 낮기 때문인 것으로 판단된다.

금융상품의 복잡성을 바라보는 관점은 크게 두 가지로 나눠볼 수 있다(Ghent et al., 2017). 첫째, '부수적 복잡성(Incidental Complexity)'의 관점인데, 보다 안전한 증권에 대한 수요에 부응하여 증권을 구조화(structuring)하는 과정에서 자연스럽게 복잡성이라는 부산 물이 생겨난다는 견해이다. 금융혁신(financial innovation) $)^{5)}$ 이 이러한 관점과 연관된다. 둘째, '고의적 복잡성(Obfuscation)' 관점인데, 증권 발행자의 전략적 의사결정으로 인해 복잡성이 생겨난다는 견해이다(Carlin, 2009). 금융회사가 의도적으로 금융상품을 복잡하게 제조함으로써 금융소비자의 합리적인 판단을 가로막아 금융소비자로부터 보다 많은 부를 착취하려는 의도로 볼 수 있다. 슈라우딩(shrouding)이 이러한 관점과 연관된다. 슈라

5) 대표적인 예로 옵션상품이 있다. Ross(1976)는 기존의 증권을 이용해서는 특정 상태(state)를 포괄 (span)하지 못하는 상황에서 옵션이 도입됨으로써 배분의 효율성(allocative efficiency)이 향상됨을 주장한다. 
Effective Regulations to the Sale of High-risk Financial Products

우딩 ${ }^{6)}$ 이란 상품의 특정 속성을 소비자가 모르게 위장함으로써 근시안적 소비자를 착취하는 전략을 의미한다(Gabaix and Laibson, 2006).

〈그림 2〉 위험 등급과 복잡성 등급을 동시에 사용한 금융투자상품 분류

Koh et al.(2015)의 <Table 1>에서 발췌한 금융투자상품 분류 행렬(matrix)이다. 세로축에 있는 위험 이라는 전통적 차원에, 가로축에 있는 복잡성이라는 새로운 차원을 추가하여 금융투자상품을 분류하고 있다.

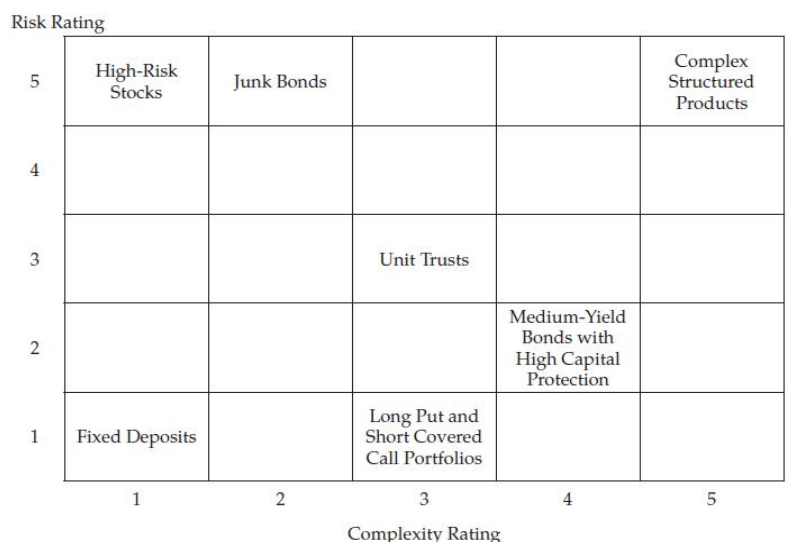

\section{4 고난도 금융투자상품}

우리나라에서는 그 동안 위험성이 높고 구조 또한 복잡한 고위험 금융상품에 대한 규제 체계가 존재하지 않았으나, 2021년 2월에 자본시장법 시행령 개정안이 의결되면서 '고난도 금융투자상품'이라는 새로운 정의 규정이 제 2 조 제 7 호에 신설되었다. 구체적인 용어정의를 살펴보면, 최대손실 가능금액이 원금의 $20 \%$ 를 초과하는 (가) 파생결합증권, (나 파생상품, 다 집합투자증권(펀드) 중에서 운용자산의 가격결정 방식, 손익구조 및 그에 따른 위험을 투자자가 이해하기 어렵다고 인정되는 것, 라 그 밖에 기초자산의 특성, 가격결정 방식, 손익구조 및 위험을 투자자가 이해하기 어렵다고 인정되는 것이다. 다만, 상장되어 거래 되는 상품과 전문투자자만을 대상으로 하는 상품은 제외된다.

\section{5 금융소비자 보호를 바라보는 두 가지 관점}

앞서 살펴보았던 복잡성에 관한 두 가지 관점과 연장선상에 있는 내용으로서, 금융소비자 보호를 바라보는 관점도 크게 두 가지로 나눠볼 수 있다. 첫째, 경쟁에 의한 시장원리와 금융소비자의 자기책임을 강조하는 전통적인 관점이다. 시장경쟁이 제대로 작동한다면 시장 내에서 고위험 금융상품은 고수익을 가져오는 가격책정(pricing)이 일어날 것이기 때문에,

6) 펀드시장에서 슈라우딩의 대표적인 사례는 일회성 비용인 수수료 대신에 지속적 비용인 보수를 부과하는 방식이다. 매영업일마다 펀드보수가 차감되더라도 포트폴리오 수익률 변동으로 인해 투자자는 자신이 부담한 펀드보수 금액을 모르게 된다. 
한국증권학회지 제51권 1호 (2022)

금융소비자는 금융상품을 비교하여 자신의 성향에 맞는 상품을 선택하고, 투자의 최종결과에 대해서는 스스로 책임질 수 있다는 것이다. 은성수 금융위원장은 DLF사태가 발생한 이후인 2019년 10월 10일, 다음과 같은 발언을 하였다. ") “예를 들어서 세상에 공짜 점심은 없다", “그러니까 투자에서는 자기책임 하에 투자하는 거기 때문에....” 금융소비자를 적절히 보호 하지 못했다는 질타를 받고 있던 부담스러운 시점임에도 불구하고 금융당국의 수장으로서 금융시장의 작동원리를 재차 강조하였던 것으로 보인다.

〈그림 3〉 슈라우딩과 탈편향의 저주

Gabaix and Laibson(2006)가 제시한 슈라우딩(shrouding)과 탈편향의 저주(curse of debiasing)라는 개념을 금융투자상품에 응용하여 도식화하였다. 착취적 회사(exploitative firm)가 근시안적 소비자 (myopic consumer)에게 고위험-저수익(high risk, low return) 상품을 판매하는 상황에서, 투명한 회사(transparent firm)가 경쟁적인 가격 책정(competitive price cutting), 교육적인 광고(educational advertising) 등의 수단을 통해 근시안적 소비자를 탈편향(debiasing) 시킨다면, 현명해진 소비자들은 기존의 시장을 떠나 $\mathrm{ETF}$ 및 인덱스펀드와 같은 금융회사에게 수익성이 낮은 시장으로 이탈하게 될 것이고, 이는 투명한 회사에게 저주(curse)가 될 것이다.

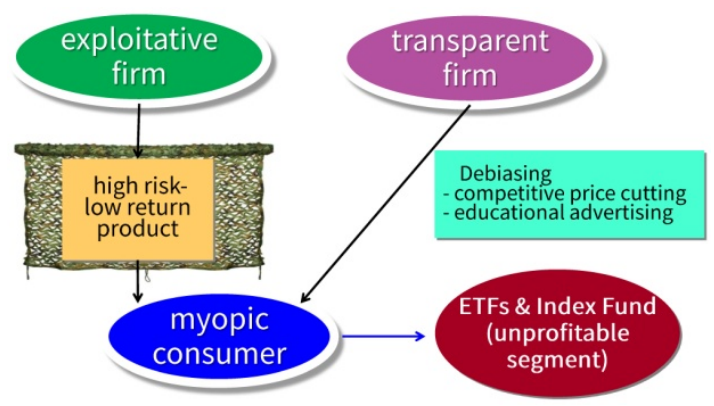

둘째, 금융소비자를 적극적으로 보호할 필요가 있다는 관점이다. 즉, 시장경쟁 원리가 항상 효율적으로 작동되는 것은 아니며 금융회사가 금융소비자를 착취할 수 있다는 것이다. 흥미있는 사례로 Gabaix and Laibson(2006)가 제시한 슈라우딩과 탈편향의 저주(curse of debiasing)라는 개념을 간략하게 살펴보기로 한다. <그림 3>은 이러한 개념을 금융투자 상품에 응용하여 도식화하였다. 슈라우딩이란 비유컨대 적군에게 발각되지 않기 위하여 군인들이 국방색 그물로 아군의 시설을 위장(camouflage)하는 것처럼, 상품에 대한 중요한 속성들을 소비자가 알지 못하게 감추는 것이다. 예를 들면 라임자산운용과 옵티머스자산 운용과 같은 착취적 회사(exploitative firm)가 근시안적 소비자(myopic consumer)에게 고위험-저수익(high risk, low return) 상품임을 눈치채지 못하게 위장하여 팔았다고 가정 해보자. 이러한 상황에서 시장경쟁 원리가 작동할 것인가? 투명한 회사(transparent firm)가 출현하여 근시안적 소비자를 올바르게 교육하고, 착취적 회사보다 좋은 상품을 제공함으로써 소비자를 탈편향(debiasing) 시킬 수 있는가? 소비자들이 현명해지면 기존의 시장을 떠나

7) KBS에서 방영된 2021년 2월 7일자 ‘시사기획 창: 라임\&주가조작단’의 일부 내용을 참고하였다. 
Effective Regulations to the Sale of High-risk Financial Products

소비자에게는 유리하고, 금융회사에게는 불리한 레드오션(경쟁이 치열한 ETF나 인덱스펀드 시장)으로 옮겨가게 된다. 이는 분명 투명한 회사에게 저주(curse)가 될 것이다. 결국 착취적 회사와 투명한 회사 모두 소비자를 착취하는 것이 최적의 전략이 되고 만다.

\section{3. 고위험 금융상품 판매현황}

\subsection{ELS, DLS 판매현황}

<표 3>는 매년 말 기준으로 산출한 ELS와 DLS의 미상환 잔고 추이이다. 원금 비보장 상품인 경우 ELS 및 DLS로, 원금 보장 상품은 별도로 구분하여 ELB 및 DLB로 나타내었다. ELS, DLS 시장은 DLF사태가 발생했던 2019년에는 108조 원 규모의 큰 시장이며, 고위험 상품 판매에 대한 규제로 인해 시장규모가 26조 원 정도 감소하여 2021년 3월 말 현재 82조 원 정도의 시장을 형성하고 있다. 추가적으로 공모와 사모방식으로 구분해보면, ELS는 주로 공모시장에서, DLS는 주로 사모시장에서 인기가 있음을 알 수 있다.

〈표 3〉 ELS, DLS 미상환 잔고

금융투자협회 종합통계서비스(freesis.kofia.or.kr)에서 산출한 ELS, DLS 미상환 잔고 추이를 나타 낸다. 원금 비보장 상품인 경우 $\mathrm{ELS}, \mathrm{DLS}$ 로 구분하고, 원금 보장 상품은 별도로 구분하여 $\mathrm{ELB}$, DLB로 나타내었다. 표본기간은 2011년 말부터 2021년 3월 말까지이며 단위는 조원이다.

Panel A: 상품별 미상환 잔고

\begin{tabular}{rrrrrrrrrrrr}
\hline & 11말 & 12말 & 13말 & 14말 & 15말 & 16말 & 17말 & 18말 & 19말 & 20말 & 21.3월말 \\
\hline ELS & 21.3 & 28.3 & 25.8 & 35.8 & 45.6 & 49.5 & 34.9 & 54.1 & 48.3 & 36.3 & 30.6 \\
ELB & 8.2 & 7.7 & 12.2 & 17.7 & 17.9 & 14.1 & 16.2 & 18.3 & 22.3 & 24.3 & 24.4 \\
DLS & 4.6 & 8.2 & 12.9 & 15.4 & 17 & 17.1 & 16.7 & 16.7 & 16.4 & 9.9 & 9 \\
DLB & 3.8 & 5.4 & 10.1 & 11.5 & 14.3 & 14.7 & 17.8 & 22.1 & 20.9 & 17.3 & 18 \\
\hline 합계 & 37.9 & 49.6 & 61.0 & 80.4 & 94.8 & 95.4 & 85.6 & 111.1 & 107.9 & 87.8 & 81.9 \\
\hline
\end{tabular}

Panel B: 모집방식별 미상환 잔고

\begin{tabular}{crrrrrrrrrrr}
\hline & 11말 & 12 말 & 13말 & 14말 & 15말 & 16말 & 17말 & 18말 & 19말 & 20말 & 21.3월말 \\
\hline $\mathrm{ELS} / \mathrm{ELB}$ (공모) & 14.4 & 16.9 & 18.3 & 30.1 & 38.2 & 40.8 & 40.0 & 59.4 & 59.9 & 51.6 & 48.9 \\
$\mathrm{ELS} / \mathrm{ELB}$ (사모) & 15.2 & 19.1 & 19.7 & 23.4 & 25.3 & 22.8 & 11.1 & 12.9 & 10.7 & 9.0 & 6.0 \\
$\mathrm{DLS} / \mathrm{DLB}$ (공모) & 1.6 & 2.1 & 4.8 & 5.2 & 5.3 & 4.7 & 4.1 & 5.4 & 6.0 & 4.9 & 3.9 \\
$\mathrm{DLS} / \mathrm{DLB}$ (사모) & 6.8 & 11.5 & 18.2 & 21.7 & 26.1 & 27.1 & 30.4 & 33.3 & 31.3 & 22.3 & 23.0 \\
\hline 합계 & 37.9 & 49.6 & 61.0 & 80.4 & 94.8 & 95.4 & 85.6 & 111.1 & 107.9 & 87.8 & 81.9 \\
\hline
\end{tabular}

\section{2 펀드 유형별 순자산}

<표 4>는 매년 말 기준으로 펀드 유형별 순자산 추이이다. 먼저 시장의 전체적인 규모는 공모시장 302조 원, 사모시장 453조 원 정도를 형성하고 있다. 가장 기본적인 유형이면서 학계에서도 연구자들이 가장 관심있어 하는 유형이라고 할 수 있는 주식형의 경우 현재 공모 77 조 원, 사모 18 조 원 규모의 시장이 형성되어 있다. 앞서 살펴본 ELS, DLS 시장이 
한국증권학회지 제51권 1호 (2022)

주식형 펀드 시장과 맞먹는 큰 시장이라는 점을 확인할 수 있다. 펀드시장에서는 주로 파생형 으로 분류된 상품들이 고위험이라고 할 수 있는데, 파생형에는 ELF, DLF뿐만 아니라 파생 상품을 편입해서 운용되는 레버리지펀드와 인버스펀드 등도 포함된다. 파생형의 경우 현재 공모 25조 원, 사모 24조 원 규모의 시장이 형성되어 있다.

\section{〈표 4〉 펀드 유형별 순자산}

금융투자협회 종합통계서비스(freesis.kofia.or.kr)에서 산출한 펀드 유형별 순자산 추이를 공모펀드와 사모펀드로 구분하여 나타내었다. 표본기간은 2011년 말부터 2021년 3월 말까지이며 단위는 조 원이다.

Panel A: 공모펀드 순자산

\begin{tabular}{|c|c|c|c|c|c|c|c|c|c|c|c|}
\hline & 11말 & 12말 & 13말 & 14말 & 15말 & 16말 & 17말 & 18말 & 19말 & 20말 & 21.3월말 \\
\hline 증권 & 104.5 & 109.1 & 103.4 & 100.7 & 111.0 & 106.2 & 120.9 & 119.4 & 138.9 & 138.6 & 149.6 \\
\hline - 주식 & 79.6 & 79.7 & 72.2 & 63.6 & 63.6 & 56.1 & 68.3 & 64.5 & 73.5 & 72.2 & 76.8 \\
\hline - 혼합주식 & 5.5 & 4.9 & 5.8 & 6.0 & 4.8 & 4.4 & 6.1 & 5.6 & 5.0 & 4.6 & 4.3 \\
\hline - 혼합채권 & 6.2 & 6.4 & 7.7 & 10.8 & 18.3 & 16.5 & 12.8 & 11.7 & 11.0 & 11.4 & 13.5 \\
\hline - 채권 & 9.6 & 12.9 & 12.4 & 15.3 & 19.0 & 23.9 & 23.2 & 27.4 & 35.0 & 33.3 & 36.2 \\
\hline - 재간접 & 3.5 & 5.2 & 5.3 & 5.0 & 5.3 & 5.2 & 10.6 & 10.1 & 14.4 & 17.2 & 18.8 \\
\hline 단기금융 & 51.4 & 62.0 & 64.2 & 79.3 & 86.1 & 87.2 & 72.6 & 70.0 & 74.1 & 102.2 & 117.5 \\
\hline 파생형 & 9.9 & 11.3 & 12.7 & 13.9 & 12.7 & 14.0 & 18.4 & 18.6 & 20.7 & 25.3 & 25.4 \\
\hline 부동산 & 0.9 & 1.0 & 1.1 & 1.1 & 0.9 & 1.3 & 2.0 & 2.4 & 3.4 & 3.4 & 3.4 \\
\hline 특별자산 & 2.6 & 2.8 & 3.0 & 3.2 & 3.2 & 3.5 & 3.5 & 2.6 & 2.5 & 2.5 & 2.5 \\
\hline 혼합자산 & 0.0 & 0.0 & 0.0 & 0.0 & 0.0 & 0.0 & 0.1 & 0.5 & 2.8 & 2.7 & 3.3 \\
\hline 합계 & 169.2 & 186.3 & 184.4 & 198.1 & 213.8 & 212.2 & 217.5 & 213.6 & 242.3 & 274.7 & 301.7 \\
\hline \multicolumn{12}{|c|}{ Panel B: 사모펀드 순자산 } \\
\hline & 11말 & 12말 & 13말 & 14말 & 15말 & 16말 & 17말 & 18말 & 19말 & 20말 & 21.3월말 \\
\hline 증권 & 63.2 & 61.2 & 75.2 & 93.8 & 100.2 & 114.8 & 111.7 & 116.8 & 131.1 & 146.3 & 152.4 \\
\hline - 주식 & 7.9 & 6.6 & 7.9 & 9.9 & 11.6 & 11.4 & 14.3 & 15.4 & 15.3 & 18.5 & 18.2 \\
\hline - 혼합주식 & 5.2 & 4.4 & 4.0 & 4.3 & 3.2 & 3.5 & 3.7 & 4.0 & 4.5 & 5.0 & 5.4 \\
\hline - 혼합채권 & 11.8 & 13.1 & 15.3 & 16.9 & 12.1 & 9.8 & 7.1 & 6.1 & 5.1 & 4.9 & 5.7 \\
\hline - 채권 & 35.7 & 34.3 & 43.7 & 56.6 & 66.9 & 80.1 & 72.6 & 75.8 & 84.0 & 84.6 & 88.9 \\
\hline - 재간접 & 2.7 & 2.9 & 4.4 & 6.2 & 6.5 & 10.1 & 14.0 & 15.5 & 22.2 & 33.3 & 34.2 \\
\hline 단기금융 & 2.5 & 2.0 & 2.9 & 4.0 & 8.0 & 17.8 & 25.4 & 20.2 & 31.5 & 24.1 & 22.7 \\
\hline 파생형 & 11.4 & 20.3 & 19.5 & 19.1 & 17.9 & 22.7 & 27.2 & 28.6 & 30.5 & 24.7 & 23.6 \\
\hline 부동산 & 15.6 & 18.9 & 23.2 & 28.6 & 35.0 & 45.9 & 59.4 & 74.8 & 97.4 & 109.7 & 112.5 \\
\hline 특별자산 & 15.5 & 18.9 & 23.3 & 27.8 & 36.5 & 44.1 & 53.8 & 67.6 & 90.0 & 104.2 & 106.3 \\
\hline 혼합자산 & 0.0 & 0.0 & 0.0 & 0.0 & 2.2 & 4.9 & 11.9 & 22.7 & 35.9 & 33.6 & 35.2 \\
\hline 합계 & 108.1 & 121.3 & 144.0 & 173.2 & 199.8 & 250.2 & 289.3 & 330.6 & 416.5 & 442.7 & 452.8 \\
\hline
\end{tabular}

\section{3 파생형 펀드의 판매채널 및 투자자 유형}

〈표 5>는 매년 말 기준으로 파생형 펀드들의 판매잔고에 대해 판매채널별로 비중을 계산한 것이다. 공모펀드는 주로 은행채널에서 판매가 되고, 사모펀드는 주로 증권사채널에서 판매가 되고 있음을 알 수 있다. 또한 2019년 DLF 사태 이후 고난도 사모펀드의 은행판매를 규제 하면서부터 은행채널의 비중이 크게 감소했음을 알 수 있다. 
Effective Regulations to the Sale of High-risk Financial Products

〈표 5〉 파생형 펀드 판매채널

금융투자협회 종합통계서비스(freesis.kofia.or.kr)에서 산출한 파생형 펀드 판매채널별 비중을 공모 펀드와 사모펀드로 구분하여 나타내었다. 표본기간은 2011년 말부터 2021년 3월 말까지이다.

Panel A: 공모펀드 판매채널

\begin{tabular}{rrrrrrrrrrrr}
\hline 공모 & 11 말 & 12 말 & 13말 & 14말 & 15말 & 16말 & 17말 & 18 말 & 19 말 & 20말 & 21.3 월말 \\
\hline 증권 & $51.8 \%$ & $51.1 \%$ & $45.9 \%$ & $39.9 \%$ & $34.7 \%$ & $32.4 \%$ & $31.5 \%$ & $28.3 \%$ & $31.8 \%$ & $28.7 \%$ & $37.0 \%$ \\
은행 & $45.7 \%$ & $45.9 \%$ & $50.0 \%$ & $55.5 \%$ & $60.9 \%$ & $63.4 \%$ & $64.8 \%$ & $68.0 \%$ & $64.8 \%$ & $68.6 \%$ & $59.5 \%$ \\
보험 & $2.4 \%$ & $2.1 \%$ & $2.9 \%$ & $3.6 \%$ & $3.2 \%$ & $3.1 \%$ & $2.5 \%$ & $2.4 \%$ & $2.2 \%$ & $1.8 \%$ & $2.4 \%$ \\
기타 & $0.2 \%$ & $0.8 \%$ & $1.2 \%$ & $1.0 \%$ & $1.2 \%$ & $1.2 \%$ & $1.3 \%$ & $1.3 \%$ & $1.2 \%$ & $1.0 \%$ & $1.1 \%$ \\
\hline
\end{tabular}

Panel B: 사모펀드 판매채널

\begin{tabular}{|c|c|c|c|c|c|c|c|c|c|c|c|}
\hline 사모 & 11말 & 12말 & 13말 & 14 말 & 15말 & 16말 & 17말 & 18말 & 19말 & 20말 & 21.3월말 \\
\hline 증권 & $73.3 \%$ & $63.3 \%$ & $76.2 \%$ & $74.6 \%$ & $71.8 \%$ & $72.4 \%$ & $84.5 \%$ & $81.1 \%$ & $84.2 \%$ & $84.6 \%$ & $84.4 \%$ \\
\hline 은행 & $21.6 \%$ & $12.0 \%$ & 13 & 14 & 17 & 20 & $9.4 \%$ & 13 & 9. & & $\%$ \\
\hline 보험 & $0.4 \%$ & $18.1 \%$ & $3.8 \%$ & $1.9 \%$ & $1.5 \%$ & $1.5 \%$ & $0.7 \%$ & $0.4 \%$ & $0.6 \%$ & $0.8 \%$ & $0.7 \%$ \\
\hline 기타 & $4.6 \%$ & $6.6 \%$ & $7.0 \%$ & $9.4 \%$ & $8.9 \%$ & $5.6 \%$ & $5.4 \%$ & $5.1 \%$ & $5.7 \%$ & $9.0 \%$ & $10.3 \%$ \\
\hline
\end{tabular}

<표 6>은 투자자 유형별로 비중을 계산한 것이다. 공모펀드는 주로 개인들을 대상으로 판매되고 있으며, 사모펀드는 주로 금융기관과 일반법인을 대상으로 판매되고 있다. DLF 사태 이후 파생형 펀드가 사모형태로 개인에게 판매되는 비중은 더욱 감소하고 있는데, 이는 개인들이 사모펀드의 위험성에 대한 경각심을 가지게 되었고, 금융당국에서 사모펀드의 최소 투자금액을 1 억 원에서 3 억 원으로 상향하는 규제에 기인한 것으로 판단된다.

〈표 6〉 파생형 펀드 투자자 유형

금융투자협회 종합통계서비스(freesis.kofia.or.kr)에서 산출한 파생형 펀드 투자자 유형별 비중을 공모 펀드와 사모펀드로 구분하여 나타내었다. 표본기간은 2011년 말부터 2021년 3월말까지이다.

Panel A: 공모펀드 투자자 유형

\begin{tabular}{|c|c|c|c|c|c|c|c|c|c|c|c|}
\hline 공도 & 11말 & 12 말 & 13말 & 14 말 & 15말 & 16말 & 17말 & 18말 & 19말 & 20말 & 21.3월말 \\
\hline & $7 \%$ & $.1 \%$ & $67.7 \%$ & $8.7 \%$ & 0 & $75.3 \%$ & $\%$ & $78.9 \%$ & $8.7 \%$ & 428 & 82 \\
\hline & 2.39 & $2.3 \%$ & 2.8 & $3.6 \%$ & $4 .($ & 4. & 4.6 & 3. & $3.2 \%$ & 4. & $3.6 \%$ \\
\hline 12 & $34.0 \%$ & $34.6 \%$ & $29.5 \%$ & $27.7 \%$ & $23.4 \%$ & $20.3 \%$ & $22.0 \%$ & $17.4 \%$ & $18.1 \%$ & $11.8 \%$ & $14.1 \%$ \\
\hline
\end{tabular}

Panel B: 사모펀드 투자자 유형

\begin{tabular}{lccccccccccc}
\hline \multicolumn{1}{c}{ 사모 } & 11 말 & 12 말 & 13 말 & 14 말 & 15 말 & 16 말 & 17 말 & 18 말 & 19 말 & 20 말 & 21.3 월말 \\
\hline 개인 & $30.8 \%$ & $17.4 \%$ & $18.0 \%$ & $17.9 \%$ & $22.2 \%$ & $22.4 \%$ & $10.8 \%$ & $14.9 \%$ & $10.6 \%$ & $7.2 \%$ & $6.6 \%$ \\
일반법인 & $40.9 \%$ & $28.4 \%$ & $33.7 \%$ & $37.8 \%$ & $16.9 \%$ & $13.5 \%$ & $14.1 \%$ & $15.5 \%$ & $18.8 \%$ & $27.4 \%$ & $30.1 \%$ \\
금융기관 & $28.4 \%$ & $54.2 \%$ & $48.3 \%$ & $44.3 \%$ & $60.9 \%$ & $64.2 \%$ & $75.1 \%$ & $69.6 \%$ & $70.6 \%$ & $65.5 \%$ & $63.4 \%$ \\
\hline
\end{tabular}

\subsection{ELT, DLT 판매현황}

특정금전신탁이란 ${ }^{8)}$ 위탁자가 금전으로 납입한 신탁재산을 운용지시를 통해 신탁재산의 운용대상, 가격, 시기 등에 대하여 구체적으로 지정하고 수탁자는 위탁자의 지시에 따라

8) 신한금융투자 페이지(https://www.shinhaninvest.com)를 참조하였다. 
운용을 하고 투자의 결과가 위탁자에게 귀속되는 금융투자상품으로 정의된다. 금융투자협회 에서는 특정금전신탁 유형을 수시입출금형, 자사주형, 퇴직연금형, 자문형, 채권형, 주식형, 주가연계형, 정기예금형, 기타로 구분하는데 이 중에서 주가연계형이 ELT와 DLT 상품을 의미한다. <표 7>은 ELT, DLT 상품의 수탁총액과 계약건수 통계를 나타낸다. 이러한 상품 들이 대부분 은행채널에서 판매되고 있다는 점이 두드러지고 있다. 금융당국에서는 DLF 사태 이후 은행의 고난도 신탁상품 판매를 규제 ${ }^{9}$ 하고 있는데, 이러한 규제의 여파로 수탁 총액과 계약건수가 크게 감소하였음을 알 수 있다.

〈표 7〉ELT, DLT 수탁총액 및 계약건수

금융투자협회 종합통계서비스(freesis.kofia.or.kr)에서 산출한 주가연계형 특정금전신탁 상품의 판매 채널별 수탁총액 및 계약건수를 나타낸다. 표본기간은 2014년 말부터 2021년 2월말까지이다. 수탁 총액의 단위는 조원이다.

Panel A: 수탁총액

\begin{tabular}{|c|c|c|c|c|c|c|c|c|}
\hline & 14말 & 15말 & 16말 & 17말 & 18말 & 19말 & 20말 & 21.2월말 \\
\hline 은행 & 18.4 & 25.7 & 30.0 & 28.9 & 42.8 & 39.5 & 25.9 & 23.3 \\
\hline 증권 & 3.2 & 3.7 & 3.9 & 5.1 & 6.0 & 6.8 & 6.2 & 6.4 \\
\hline 보험 & 0.04 & 0.09 & 0.02 & 0.01 & 0.01 & & & \\
\hline 합계 & 21.6 & 29.5 & 33.9 & 33.9 & 48.8 & 46.4 & 32.2 & 29.7 \\
\hline \multicolumn{9}{|c|}{ Panel B: 계약건수 } \\
\hline & 14 말 & 15말 & 16말 & 17말 & 18말 & 19말 & 20말 & 21.2월말 \\
\hline 은행 & 398,218 & 543,168 & 656,790 & 618,862 & 880,092 & 787,281 & 467,246 & 395,638 \\
\hline 증권 & 23,142 & 20,510 & 15,409 & 12,509 & 14,829 & 17,160 & 11,581 & 9,306 \\
\hline 보험 & 0.04 & 0.09 & 0.02 & 0.01 & 0.01 & & & \\
\hline 합계 & 21.6 & 29.5 & 33.9 & 33.9 & 48.8 & 46.4 & 32.2 & 29.7 \\
\hline
\end{tabular}

\section{4. 금융당국의 고위험 금융상품 관련 제도 개선방안}

\section{1 고위험 금융상품 투자자 보호 강화를 위한 종합 개선방안}

<표 8>은 금융위원회와 금융감독원이 2019년 12월 12일에 발표한 '고위험 금융상품 투자자 보호 강화를 위한 종합 개선방안(최종안) ${ }^{10)}$ 을 요약한 것이다. 금융소비자 보호 측면 에서 중요하다고 판단되는 주요 내용들을 선별적으로 살펴보기로 하자. 첫째, 고난도 금융 투자상품이라는 개념과 관련 규제가 도입되었다는 점이다. 자본시장법 시행령 제68조 (5) 항은 고난도 금융투자상품을 판매할 때에는 판매과정을 녹취하고, 청약을 철회할 수 있는

9) 다만, 주요 시장지수(KOSPI200, S\&P500, Eurostoxx50, HSCEI, NIKKEI225)가 기초자산이며, 공모로 발행되고, 손실배수가 1 이하인 파생결합증권은 2019년 11월 말 기준 은행별 잔액 이내 에서 신탁판매가 예외적으로 허용된다.

10) Financial Services Commission and Financial Supervisory Service(2019). 
Effective Regulations to the Sale of High-risk Financial Products

숙려기간을 부여하도록 하고 있다. 복잡성이 높은 상품을 규제하는 체계를 최초로 만들어 불완전판매를 감소시키려는 시도를 했다는 측면에서 의미가 크다고 판단된다. 둘째, 은행의 고난도 사모펀드, 고난도 신탁 판매를 금지하였다는 점이다. 은행을 이용하는 고객들은 은행에서 판매되는 상품을 원금이 보장되는 상품으로 오인하는 경우가 많기 때문에 도입된 규제라고 할 수 있다. 셋째, 전문투자형 사모펀드(헤지펀드)에 투자하기 위한 일반투자자의 최소 투자금액을 1 억 원에서 3 억 원 이상으로 상향시켰다는 점이다. 충분한 손실감수능력이 없는 투자자들의 고위험 사모펀드 투자를 막고, 사모펀드 시장을 고액자산가 및 전문투자자 중심의 시장으로 유도하기 위한 규제라고 할 수 있다. 넷째, 고난도 금융투자상품의 제조사와 판매사가 영업단계별로 준수해야 할 사항들을 정리한 표준영업행위준칙을 도입했다는 점이다. 준칙의 작성은 금융투자회사들의 자율규제기구인 금융투자협회에서 담당하도록 하였다. 다섯째, OEM(original equipment manufacturer) 펀드 ${ }^{11)}$ 판매사의 제재근거를 마련하고, $\mathrm{OEM}$ 펀드 적용기준도 강화하였다는 점이다. 판매사가 가지는 우월한 지위를 이용하여 판매보수 및 수수료 수익을 증대하기 위해 펀드운용에 불법적으로 관여하는 것을 막겠다는 것이다. 여섯째, 감독 행정을 적극 활용하여 판매사의 경영실태평가시 $\mathrm{KPI}(\mathrm{key}$ performance indicator)의 적정성을 점검하겠다는 것이다. 지나치게 판매성과 위주로 설정된 $\mathrm{KPI}$ 에 고객 수익률, 금융소비자보호 등을 반영하여, 고위험 금융상품의 불완전판매를 줄이려는 취지 라고 할 수 있다.

〈표 8〉고위험 금융상품 투자자 보호 강화를 위한 종합 개선방안

금융위원회와 금융감독원이 2019년 12월 12일에 발표한 '고위험 금융상품 투자자 보호 강화를 위한 종합 개선방안(최종안)'에서 III장(제도개선 기본 원칙 및 방향) 및 IV장(세부 추진방안)의 주요내용을 요약하였다.

\begin{tabular}{|c|c|c|}
\hline 구분 & 개선방안 & 주요내용 \\
\hline \multirow{4}{*}{$\begin{array}{l}\text { 투자자 보호 } \\
\text { 강화 }\end{array}$} & $\begin{array}{l}\text { 1. 공모판단 기준 } \\
\text { 강화 }\end{array}$ & $\begin{array}{l}\text { - 실질적 공모상품이 사모형식으로 판매되지 않도록 } \\
\text { 차단 } \\
\text { - 기초자산과 손익구조가 유사한 경우 원칙적으로 공모 } \\
\text { 로 판단 }\end{array}$ \\
\hline & $\begin{array}{l}\text { 2. 고난도 금융상품 } \\
\text { 도입 }\end{array}$ & $\begin{array}{l}\text { - 투자자의 이해가 어렵고 원금손실가능비율이 } 20 \% \text { 를 } \\
\text { 초과하는 경우 고난도 금융상품으로 분류하고 투자자 } \\
\text { 보호 장치 강화 }\end{array}$ \\
\hline & $\begin{array}{l}\text { 3. 은행의 고난도 } \\
\text { 사모펀드 판매 } \\
\text { 제한 }\end{array}$ & $\begin{array}{l}\text { - 고난도 사모펀드, 신탁을 판매금지 } \\
\text { - 공모펀드 중심 판매채널로 전환 }\end{array}$ \\
\hline & $\begin{array}{l}\text { 4. 전문투자형 사모 } \\
\text { 펀드(헤지펀드) } \\
\text { 일반투자자 요건 } \\
\text { 강화 }\end{array}$ & $\begin{array}{l}\text { - 사모펀드 최소투자금액을 3억 원 이상으로 상향 } \\
\text { - 줄어드는 투자기회는 사모 재간접펀드를 통해 보완 }\end{array}$ \\
\hline
\end{tabular}

11 ) 자산운용사가 판매사로부터 명령·지시·요청 등을 받아 운용하는 펀드를 의미한다. 자본시장법 시행령 제 87 조에서는 이러한 $\mathrm{OEM}$ 펀드 운용을 불건전 영업행위로 금지하고 있다. 
〈표 8〉 고위험 금융상품 투자자 보호 강화를 위한 종합 개선방안(계속)

\begin{tabular}{|c|c|c|}
\hline 구분 & 개선방안 & 주요내용 \\
\hline \multirow{3}{*}{$\begin{array}{l}\text { 투자자 보호 } \\
\text { 강화 }\end{array}$} & $\begin{array}{l}\text { 5. 녹취·숙려제도 } \\
\text { 강화 }\end{array}$ & $\begin{array}{l}\text { - 녹취·숙려제도 적용대상을 대폭 확대하여 } 65 \text { 세 이상의 } \\
\text { 고령투자자와 부적합투자자, 고난도 금융상품에 투자 } \\
\text { 하는 모든 일반투자자에게 적용 }\end{array}$ \\
\hline & $\begin{array}{l}\text { 6. 설명의무 등 } \\
\text { 판매절차 강화 }\end{array}$ & $\begin{array}{l}\text { - 단순 확인방식이 아닌 자필 또는 육성 진술하는 절차만 } \\
\text { 인정 } \\
\text { - 투자자성향 분류현황 } \mathrm{DB} \text { 화 } \\
\text { - 투자자성향 조작행위, 투자상품 위험도 낮추는 행위 } \\
\quad \text { 제재 }\end{array}$ \\
\hline & $\begin{array}{l}\text { 7. 개인전문투자자 } \\
\text { 보호장치 보완 }\end{array}$ & $\begin{array}{l}\text { - 개인전문투자자에게도 고난도 금융 상품 판매시 설명 } \\
\quad \text { 의무 강화 } \\
\text { - 개인전문투자자 정보 } \mathrm{DB} \text { 화 }\end{array}$ \\
\hline \multirow{5}{*}{$\begin{array}{l}\text { 금융회사의 } \\
\text { 책임성 확보 } \\
\text { 및 감독강화 }\end{array}$} & $\begin{array}{l}\text { 1. 경영진 책임 및 } \\
\text { 내부통제 강화 }\end{array}$ & $\begin{array}{l}\text { - 책임있는 의사결정을 하도록 내부통제기준 마련 및 } \\
\text { 관리책임 명확화 }\end{array}$ \\
\hline & $\begin{array}{l}\text { 2. 고난도 금융상품 } \\
\text { 영업행위준칙 } \\
\text { 시행 }\end{array}$ & $\begin{array}{l}\text { - 제조사와 판매사가 연계하여 영업단계별로 준수하여야 } \\
\text { 할 행위준칙 마련 }\end{array}$ \\
\hline & $\begin{array}{l}\text { 3. OEM펀드 판매사 } \\
\text { 책임 및 규제적용 } \\
\text { 기준 강화 }\end{array}$ & $\begin{array}{l}\text { - 판매사에 대한 제재근거를 마련하고, 현행 OEM 펀드 } \\
\text { 적용기준을 최대한 폭 넓게 해석하여 엄격하게 규율 }\end{array}$ \\
\hline & $\begin{array}{l}\text { 4. 불완전판매 관련 } \\
\text { 제재 강화 }\end{array}$ & $\begin{array}{l}\text { - 금융소비자보호법 제정을 통해 불완전판매에 대한 제 } \\
\text { 재를 강화하고, 불완전판매 사전 예방효과 제고 }\end{array}$ \\
\hline & $\begin{array}{l}\text { 5. 금융당국의 상시 } \\
\text { 감시·감독 강화 }\end{array}$ & $\begin{array}{l}\text { - 일부상품으로의 쏠림 현상, 손실가능성 등 모니터링 } \\
\text { - 판매 영업행위에 대한 모니터링 및 현장점검 }\end{array}$ \\
\hline $\begin{array}{l}\text { 투자자 보호 } \\
\text { 강화를 위한 } \\
\text { 보완 조치 }\end{array}$ & $\begin{array}{l}\text { 감독 행정을 적극 } \\
\text { 활용 }\end{array}$ & $\begin{array}{l}\text { - 행정지도 시행 및 은행의 고위험상품 판매 관련 감독 } \\
\text { 강화 } \\
\text { - 경영실태평가시 } \mathrm{KPI} \text { 적정성 점검(고객수익률 연동 성 } \\
\text { 과체계 등) } \\
\text { - 엄정한 제재 및 분쟁조정 }\end{array}$ \\
\hline
\end{tabular}

\section{2 고난도 금융투자상품 제조 및 판매에 관한 표준영업행위준칙}

<표 9>는 금융투자협회가 2020년 6월 25일에 발표한 '고난도 금융투자상품 제조 및 판매에 관한 표준영업행위준칙 ${ }^{12)}$ 의 주요내용을 요약한 것이다. 준칙은 크게 금융투자 상품의 제조회사가 준수해야 할 사항과 판매회사가 준수해야 할 사항으로 나누어진다. 몇 가지 중요한 내용들을 살펴보기로 하자. 첫째, 제조회사가 잠재적 목표시장(어떤 고객에게 판매할 것인지)과 판매전략(공모/사모, 증권/펀드/신탁/일임, 판매채널 등)을 도출하라는 것이다. 이는 제조단계에서부터 불완전 판매의 불씨를 원천적으로 차단해보겠다는 취지라고 판단된다. 둘째, 제조회사는 금융투자상품 테스트를 다양한 부정적인 상황을 가정하고 수행해야 한다는 것이다. 단순히 과거의 시장상황 만을 가정하고 $100 \%$ 안전하다는 설명

12) Korea Financial Investment Association(2020). 
Effective Regulations to the Sale of High-risk Financial Products

자료를 만들어 투자자를 오인하도록 하는 문제를 막기 위한 준칙이라고 할 수 있다. 셋째, 판매회사는 제조회사가 도출한 잠재적 목표시장과 판매전략을 기반으로 실제 이용가능한 고객정보를 기초로 하여 구체적 목표시장과 판매전략을 설정하라는 것이다. 평생 은행 예적금 만을 이용해왔던 고객, 금융이해력이 낮은 고객 등에게 고난도 금융상품이 판매되지 않도록 하는 등 적합성 원칙이 판매일선에서 준수되도록 유도하는 준칙이라고 할 수 있다. 넷째, 판매회사는 고난도 금융상품 판매 후에도 목표시장 및 판매전략에 대해 정기적으로 점검 하고 오류발견시 적절한 시정조치를 취해야 하며, 손실률과 같은 중요한 정보를 고객에게 수시로 제공해야 한다는 것이다. 판매회사는 고객의 투자기간 동안 지속적으로 판매보수를 수취하거나, 판매보수에 상당하는 금액을 판매시점에서 일시에 수수료로 선취하기 때문에 판매회사 역할은 판매시에 종료되어서는 안되며, 판매 후에도 책임과 역할을 다해야 함을 말해주는 준칙이라고 할 수 있다.

〈표 9〉 고난도 금융투자상품 제조 및 판매에 관한 표준영업행위준칙 금융투자협회가 2020년 6월 25일에 발표한 '고난도 금융투자상품 제조 및 판매에 관한 표준영업행위 준칙'의 주요내용을 요약하였다.

\begin{tabular}{|c|c|c|}
\hline 대상 & 준수사항 & 주요내용 \\
\hline \multirow{10}{*}{$\begin{array}{l}\text { 제조 } \\
\text { 회사 }\end{array}$} & 1. 일반원칙 & - 고객 이익 최우선, 업무수행 과정의 기록을 충실히 유지 \\
\hline & $\begin{array}{l}\text { 2. 금융투자상품 관리체계의 } \\
\text { 마련 }\end{array}$ & - 내부통제기준에 따라 자체적으로 상품승인절차 운영 \\
\hline & $\begin{array}{l}\text { 3. 복수회사의 금융투자상품 } \\
\text { 제조 }\end{array}$ & $\begin{array}{l}\text { - 하나의 목표시장을 설정하고 제조 관련 상호 업무 } \\
\text { 및 책임 범위 설정 }\end{array}$ \\
\hline & 4. 목표시장 및 판매전략 설정 & $\begin{array}{l}\text { - 고객과 금융투자상품의 특성을 고려하여 잠재적 목표 } \\
\text { 시장 설정 }\end{array}$ \\
\hline & 5. 금융투자상품 테스트 & $\begin{array}{l}\text { - 발생가능한 손실위험에 대해 다양한 부정적인 시장 } \\
\text { 상황 하에서의 시나리오 분석 실시 } \\
\end{array}$ \\
\hline & 6. 판매회사에 대한 정보제공 & $\begin{array}{l}\text { - 원활한 정보교환을 위한 체계 구축하고 상품에 대한 } \\
\text { 충분한 정보 제공 }\end{array}$ \\
\hline & 7. 금융투자상품 점검 & - 사후점검 및 모니터링 정기적으로 수행 \\
\hline & 8. 이해상충방지 체계 & - 제조과정에서 이해상충을 관리할 수 있는 절차 확립 \\
\hline & $\begin{array}{l}\text { 9. 감독체계 및 임직원 자격 } \\
\text { 요건 }\end{array}$ & $\begin{array}{l}\text { - 이사회는 영업행위준칙 마련, 대표이사는 운영체계를 } \\
\text { 관리, 준법감시인 또는 금융소비자보호총괄책임자는 } \\
\text { 운영체계를 모니터링, 제조에 관여하는 임직원은 상 } \\
\text { 품에 대한 이해를 갖출 것 } \\
\end{array}$ \\
\hline & 10. 점검보고서 & $\begin{array}{l}\text { - 준법감시인 또는 금융소비자보호총괄책임자는 영업 } \\
\text { 행위준칙과 관련한 점검보고서를 이사회에 보고 }\end{array}$ \\
\hline \multirow{4}{*}{$\begin{array}{l}\text { 판매 } \\
\text { 회사 }\end{array}$} & 1. 일반원칙 & $\begin{array}{l}\text { - 고객 이익 최우선, 업무수행 과정의 기록을 충실히 } \\
\text { 유지 }\end{array}$ \\
\hline & 2. 금융투자상품 관리체계의 마련 & - 내부통제기준에 따라 자체적으로 상품승인절차 운영 \\
\hline & 3. 판매업무 일반 & $\begin{array}{l}\text { - 상품을 충분히 이해하고 고객의 니즈 충족여부, 고객 } \\
\text { 의 상황을 고려 }\end{array}$ \\
\hline & 4. 제조회사로부터 정보 & $\begin{array}{l}\text { - 원활한 정보교환을 위한 체계 구축하고 충분한 정보를 } \\
\text { 확보 }\end{array}$ \\
\hline
\end{tabular}


〈표 9〉고난도 금융투자상품 제조 및 판매에 관한 표준영업행위준칙(계속)

\begin{tabular}{|c|c|c|}
\hline 대상 & 준수사항 & 주요내용 \\
\hline \multirow{7}{*}{$\begin{array}{l}\text { 판매 } \\
\text { 회사 }\end{array}$} & 5. 목표시장 및 판매전략 & - 구체적 목표시장 및 판매전략 설정 \\
\hline & $\begin{array}{l}\text { 6. 목표시장 설정과 판매규제 } \\
\text { 준수 }\end{array}$ & $\begin{array}{l}\text { - 목표시장 범위 내에서, 적합한 투자자에게 판매규제를 } \\
\text { 준수하면서 상품을 판매 }\end{array}$ \\
\hline & $\begin{array}{l}\text { 7. 감독체계 및 임직원 자격 } \\
\text { 요건 }\end{array}$ & $\begin{array}{l}\text { - 이사회는 영업행위준칙 마련, 대표이사는 운영체계를 } \\
\text { 관리, 준법감시인 또는 금융소비자보호총괄책임자는 } \\
\text { 운영체계를 모니터링, 판매에 관여하는 임직원은 } \\
\text { 상품에 대한 이해를 갖출 것 }\end{array}$ \\
\hline & 8. 점검보고서 & $\begin{array}{l}\text { - 준법감시인 또는 금융소비자보호총괄책임자는 영업 } \\
\text { 행위준칙과 관련한 점검보고서를 이사회에 보고 }\end{array}$ \\
\hline & 9. 판매 후 점검 & $\begin{array}{l}\text { - 목표시장 및 판매전략 설정 등의 운영실태 정기적 } \\
\text { 점검, 목표시장 설정 오류시 제조회사에 통보해 } \\
\text { 적절한 시정조치, 고객에게 수익률 또는 손실률 등 } \\
\text { 관련 정보 수시로 제공 }\end{array}$ \\
\hline & 10. 제조회사에 대한 & $\begin{array}{l}\text { - 목표시장 및 판매전략 설정, 판매현황 분석자료 등을 } \\
\text { 제공 }\end{array}$ \\
\hline & 11. 목표시장 외 판매 & - 목표시장 외의 고객에게 판매시 합리적 사유 필요 \\
\hline
\end{tabular}

\section{3 사모펀드 제도개선 방안}

<표 10〉은 금융위원회와 금융감독원이 2020년 4월 27일에 발표한 '사모펀드 현황 평가 및 제도개선 방안(최종안) ${ }^{13)}$ 을 요약한 것이다. 개선방안은 4 개 범주(시장규율을 통한 위험 관리 강화, 투자자 정보제공 강화, 투자자보호 취약구조에 대한 보완, 금융당국 감독·검사)로 나누어져 있다. 전반적으로 많은 규제가 도입되었는데 감독, 점검, 보고서, 설명자료 등에 있어 공모펀드 규제가 상당부분 차용된 것으로 보인다. 이에 대해 업계에서는 규제와 감독 으로부터 자유로운 과감한 자산운용을 통해 금융시장에 고위험 감수 모험자본을 공급한다는 사모펀드의 취지를 훼손할 수 있다는 우려도 존재한다. 방안의 주요 내용을 개관하면 다음과 같다. 첫째, 펀드재산 평가에 대한 공정성 확보이다. 사모펀드에서 시가평가가 어려운 자산에 투자하였을 때 운용사 임의대로 시가를 평가하고, 이를 악용하여 펀드 간에 부실을 전이시키는 등의 사례가 지적되었다. 공정가액 평가 기준을 마련하고, 제 3 의 독립기관 평가 및 외부감사를 도입하여 사모펀드가 투자한 자산을 공정하게 평가하겠다는 것이다. 둘째, 사모펀드 운용사가 수탁고의 $0.03 \%$ 를 손해배상재원으로 적립하도록 강제하여 운용사의 손해배상책임능력을 확충하겠다는 것이다. 이는 금융투자업규정 제3-24조의3에 따라 고객 자산운용에 필요한 최소영업자본으로 $0.02 \sim 0.03 \%$ 를 ${ }^{14)}$ 적립하도록 한 공모펀드 규제에서 차용되었다고 할 수 있다. 셋째, 사모펀드의 투자설명자료에 기재되는 내용을 표준화하고,

13) Financial Services Commission and Financial Supervisory Service(2020).

14) 금융투자업규정시행세칙 별표 8 의 2 와 자본시장법 제 229 조에 따르면 증권펀드의 경우 $0.02 \%$, 그 외의 펀드(부동산펀드, 특별자산펀드, 혼합자산펀드, 단기금융펀드)는 $0.03 \%$ 의 적립률을 적용 하도록 되어 있다. 
기재내용과 어긋난 운용행위를 제재한다는 것이다. 이는 공모펀드에서 표준화된 투자설명서 및 간이투자설명서를 사용하고, 운용방식이 투자설명서와 어긋나는 경우 불건전영업행위로 제재하는 규제를 사모펀드로 가져온 것이다. 넷째, 사모펀드 투자자에게 분기별 자산운용 보고서를 제공해야 한다는 것이다. 이 또한 공모펀드의 분기 자산운용보고서 규제를 그대로 차용한 것으로 볼 수 있다. 다섯째, 개방형 펀드에 대해 유동성 스트레스 테스트를 최소 연1회 실시토록 하고, 시나리오별 비상계획을 마련토록 하였다. 또한, 비시장성 자산에 집중 하여 투자하는 펀드는 개방형을 금지하고 폐쇄형으로 설정하도록 하였다. 이는 투자자들의 환매 니즈와 비시장성 자산 간에 만기 미스매치로 유동성 문제가 발생하여 환매가 중지되는 사태를 방지하기 위함이라 할 수 있다. 여섯째, TRS(total return swap) 계약을 통해 일으킨 레버리지를 사모펀드에 명확하게 반영하도록 하였다는 점이다. 사모펀드에서는 $400 \%$ 까지 레버리지가 허용되는데, TRS를 통한 레버리지가 사모펀드 레버리지 한도에 과소 반영되고, 투자자도 이를 인지하지 못하는 경우가 많았고, 펀드손실 발생시 펀드투자자보다 채권자가 우선변제권을 가지므로 펀드투자자의 손실이 커질 수 있기 때문이다.

\section{〈표 10〉사모펀드 제도개선 방안}

금융위원회와 금융감독원이 2020년 4월 27일에 발표한 '사모펀드 현황 평가 및 제도개선 방안(최종안)' 에서 III장(전문투자형 사모펀드 제도개선 기본방향) 및 IV장(세부 추진방안)의 주요내용을 요약하였다.

\begin{tabular}{|c|c|c|}
\hline 구분 & 개선방안 & 주요내용 \\
\hline \multirow{5}{*}{$\begin{array}{l}\text { 시장규율을 } \\
\text { 통한 } \\
\text { 위험관리 } \\
\text { 강화 }\end{array}$} & $\begin{array}{l}\text { 1. 운용사의 내부통제 } \\
\text { 및 의사결정구조 } \\
\text { 강화 }\end{array}$ & $\begin{array}{l}\text { - 내부통제·위험관리를 위한 check-list 마련하여 제공 } \\
\text { - 운용규모 } 2 \text { 천억 이상 운용사는 내부통제·위험관리 } \\
\text { 이행내역을 감독당국에 보고, } 2 \text { 천억 이하 운용사는 } \\
\text { 금투협에서 자율점검 }\end{array}$ \\
\hline & $\begin{array}{l}\text { 2. 운용사의 펀드재산 } \\
\text { 평가에 대한 공정성 } \\
\text { 확보 }\end{array}$ & $\begin{array}{l}\text { - 비시장성 자산 공정가액 평가기준 마련 } \\
\text { - 자전거래시 시가 없는 자산에 대한 제 } 3 \text { 의 독립기관이 } \\
\text { 평가 } \\
\text { - 일정규모 이상 사모펀드에 대해 공모펀드 기준으로 } \\
\text { 외부감사 }\end{array}$ \\
\hline & $\begin{array}{l}\text { 3. 운용사의 손해 } \\
\text { 배상책임 능력 확충 }\end{array}$ & $\begin{array}{l}\text { - 운용사별로 수탁고의 } 0.03 \% \text { 를 손해배상재원으로 } \\
\text { 적립 }\end{array}$ \\
\hline & $\begin{array}{l}\text { 4. 판매사의 펀드 } \\
\text { 운용에 대한 견제 } \\
\text { 기능 도입 }\end{array}$ & $\begin{array}{l}\text { - 판매 전에는 투자설명자료의 적정성 검증 } \\
\text { - 판매 후에는 투자설명자료상의 투자전략 및 운용방법 } \\
\text { 에 맞게 운용되는지 점검 }\end{array}$ \\
\hline & $\begin{array}{l}\text { 5. 수탁기관 및 } \mathrm{PBS} \\
\text { 증권사의 관리. } \\
\text { 감시책임 부여 }\end{array}$ & $\begin{array}{l}\text { - 법령·규약·투자설명자료 위반여부를 확인하고 운용 } \\
\text { 사에 시정 요구 }\end{array}$ \\
\hline \multirow[t]{2}{*}{$\begin{array}{l}\text { 투자자 } \\
\text { 정보제공 } \\
\text { 강화 }\end{array}$} & $\begin{array}{l}\text { 1. 적격일반투자자에 } \\
\text { 대한 상품 설명 } \\
\text { 의무 강화 }\end{array}$ & $\begin{array}{l}\text { - 적격일반투자자에 대한 투자설명자료 기재사항을 } \\
\text { 표준화 } \\
\text { - 투자설명자료에 기재된 내용을 위반하여 운용하는 } \\
\text { 경우 불건전영업행위로 엄정제재 }\end{array}$ \\
\hline & $\begin{array}{l}\text { 2. 운용사의 운용관련 } \\
\text { 정보제공 강화 }\end{array}$ & - 적격일반투자자에 대한 분기별 자산운용보고서 제공 \\
\hline
\end{tabular}


〈표 10〉사모펀드 제도개선 방안(계속)

\begin{tabular}{|c|c|c|}
\hline 구분 & 개선방안 & 주요내용 \\
\hline \multirow{3}{*}{$\begin{array}{l}\text { 투자자보호 } \\
\text { 취약구조에 } \\
\text { 대한 보완 }\end{array}$} & $\begin{array}{l}\text { 1. 펀드 유동성 } \\
\text { 리스크 관리를 } \\
\text { 위한 체계 마련 }\end{array}$ & $\begin{array}{l}\text { - 개방형 펀드에 대한 유동성 스트레스테스트 실시하고 } \\
\text { 비상계획 마련 의무화 } \\
\text { - 비시장성 자산 투자비중이 } 50 \% \text { 이상인 일반투자자 } \\
\text { 대상펀드의 경우 개방형 펀드로 설정 금지 }\end{array}$ \\
\hline & $\begin{array}{l}\text { 2. 복층·순환 투자 } \\
\text { 구조 펀드에 대한 } \\
\text { 관리 강화 }\end{array}$ & $\begin{array}{l}\text { - 개방형 펀드에 폐쇄형 펀드 편입시 유동성 규제 적용 } \\
\text { - 펀드 투자자 수 산정시 실직적으로 투자한 모든 자사 } \\
\text { 펀드 투자자 수까지 합산 } \\
\text { - 자사펀드간 상호 순환투자 행위 금지 }\end{array}$ \\
\hline & $\begin{array}{l}\text { 3. TRS 등을 통한 } \\
\text { 차입운용 펀드에 } \\
\text { 대한 투자자 보호 } \\
\text { 장치 마련 }\end{array}$ & $\begin{array}{l}\text { - TRS 등 차입운용 관련 내용을 투자설명자료 및 자산 } \\
\text { 운용보고서에 충실히 기재하고, 집합투자규약에 사전 } \\
\text { 반영 } \\
\text { - TRS 계약을 통해 일으킨 레버리지를 사모펀드 레버 } \\
\text { 리지 한도에 명확히 반영 }\end{array}$ \\
\hline \multirow{5}{*}{$\begin{array}{l}\text { 금융당국 } \\
\text { 감독·검사 } \\
\text { 강화 }\end{array}$} & $\begin{array}{l}\text { 1. 상시 모니터링을 } \\
\text { 위한 감독당국 } \\
\text { 보고의무 강화 } \\
\end{array}$ & $\begin{array}{l}\text { - 사모펀드 영업보고서 제출 주기를 분기로 단축 } \\
\text { - 영업보고서에 레버리지 현황보고를 강화하고, 자산 } \\
\text { 운용보고서 주요내용 등을 영업보고서에 반영토록 함 }\end{array}$ \\
\hline & $\begin{array}{l}\text { 2. 사전예방적 검사 } \\
\text { 시스템 구축 }\end{array}$ & $\begin{array}{l}\text { - 이상징후(운용규모 급증 운용사, 리테일 판매량 급증 } \\
\text { 펀드, 고위험펀드, 수수료가 과도한 펀드 등) 발견시 } \\
\text { 집중 검사 }\end{array}$ \\
\hline & $\begin{array}{l}\text { 3. 불건전 영업행위 } \\
\text { 제재 강화 }\end{array}$ & $\begin{array}{l}\text { - 펀드자금 투자를 조건으로 투자자에게 펀드 가입을 } \\
\text { 강요하는 꺾기 행위 금지 } \\
\text { - } 1 \text { 인 펀드 설정금지 규제회피 차단 }\end{array}$ \\
\hline & $\begin{array}{l}\text { 4. 부실 전문사모 } \\
\text { 운용사 적극 퇴출 }\end{array}$ & $\begin{array}{l}\text { - 부실화된 운용사의 경우 패스트트랙으로 등록말소 } \\
\text { - 부실업체를 적시 퇴출하여 다산다사(多産多死) 체계 } \\
\text { 구축 }\end{array}$ \\
\hline & $\begin{array}{l}\text { 5. 금융투자협회의 } \\
\text { 자율규제 기능 } \\
\text { 활성화 }\end{array}$ & $\begin{array}{l}\text { - 사모펀드 시장에 대한 모니터링과 회원조사 기능을 } \\
\text { 강화하고, 비회원사의 회원가입 유도 } \\
\text { - 내부통제·위험관리 이행내역에 대한 전수조사 및 } \\
\text { 취약사 컨설팅 }\end{array}$ \\
\hline
\end{tabular}

\section{4 파생결합증권시장 건전화 방안}

<표 11>은 금융위원회, 금융감독원, 한국거래소, 금융투자협회가 2020년 7월 31일에 발표한 '파생결합증권시장 건전화 방안 ${ }^{15)}$ 을 요약한 것이다. 개선방안은 3 개 범주(증권회사 건전성 제고, 금융시장 시스템리스크 전이 차단, 투자자 보호 강화)로 나누어져 있다. 몇 가지 중요한 내용들을 위주로 살펴보기로 한다. 첫째, 스트레스 테스트 시나리오에 극단적 상황을 포함시키고 그 결과를 금융감독원이 점검하겠다는 것이다. 보고서에서는 극단적 시나리오 예시로 전일 대비 기초자산의 $5 \%$ 50\% 하락을 제시하였다. 둘째, 원금비보장 파생결합증권이 과다 발행되는 유인을 차단하기 위해서, 파생결합증권 발행액이 클수록 부채반영비율을 차등하여 상향 조정한다는 것이다. 예를 들면 2021년에 파생결합증권 발행

15) Financial Services Commission et al.(2020). 
Effective Regulations to the Sale of High-risk Financial Products

규모가 자기자본 대비 $50 \%$ 이하이면 파생결합증권의 부채반영비율은 $100 \%$ 이지만, 발행 규모가 자기자본 대비 $200 \%$ 를 초과하면 부채반영비율이 $150 \%$ 까지 상승하게 된다. 셋째, 파생결합증권 통합정보플랫폼과 환매인프라를 구축한다는 것이다. 파생결합증권은 여러 상품간 비교가 어렵고, 만기 전에는 환매가 어렵다는 문제를 개선하기 위한 방안이다. 넷째, 조건 충족시 수익률과 조건 미충족시 손실률을 같은 크기로 균형 있게 근접하여 표시토록 함으로써 투자자 오해 및 불완전판매를 차단하겠다는 것이다.

〈표 11〉 파생결합증권시장 건전화 방안

금융위원회, 금융감독원, 한국거래소, 금융투자협회가 2020년 7월 31일에 발표한 '파생결합증권 시장 건전화 방안'에서 III장(개선방안)의 주요내용을 요약하였다.

\begin{tabular}{|c|c|c|}
\hline 구분 & 개선방안 & 주요내용 \\
\hline \multirow[b]{2}{*}{$\begin{array}{l}\text { 증권회사 } \\
\text { 건전성 제고 }\end{array}$} & $\begin{array}{l}\text { 1. 증권회사 자체 } \\
\text { 리스크 관리 } \\
\text { 여랴 갛하. }\end{array}$ & $\begin{array}{l}\text { - 스트레스 테스트 시나리오에 최근의 극단적 상황을 포 } \\
\text { 함시키고 그 결과를 금감원이 점검 } \\
\text { - 즈궣ㅎ사벼 }\end{array}$ \\
\hline & $\begin{array}{l}\text { 2. 유동성 비율 } \\
\text { 제도 내실화 }\end{array}$ & $\begin{array}{l}\text { - 증권회사별 ELS 자체헤지 관련 외화조달 비상계획 구축 } \\
\text { - 최종만기가 아닌 조기상환 시점을 기준으로 유동부채 산정 } \\
\text { - 파생결합증권 발행 증권회사에 대해 종합금융투자사업 } \\
\text { 자와 동일한 원화 유동성 비율 규제 적용 }\end{array}$ \\
\hline \multirow{2}{*}{$\begin{array}{l}\text { 금융시장 } \\
\text { 시스템리스크 } \\
\text { 전이 차단 }\end{array}$} & $\begin{array}{l}\text { 1. 레버리지비율 } \\
\text { 규제 강화 }\end{array}$ & $\begin{array}{l}\text { - 적격일반투자자에 대한 투자설명자료 기재사항을 표준화 } \\
\text { - 원금비보장 파생결합증권의 발행액이 클수록 부채금액 반 } \\
\text { 영비율 가중치를 상향 적용하여 과다 발행 유인을 차단 } \\
\end{array}$ \\
\hline & $\begin{array}{l}\text { 2. 헤지자산 분산 } \\
\text { 투자 }\end{array}$ & $\begin{array}{l}\text { - 해외지수가 기초자산인 파생결합증권 자체헤지 규모의 } \\
\text { 일정수준을 외화 유동자산 등으로 보유토록 의무화 } \\
\text { - 헤지자산으로 여전채는 } 10 \% \text { 까지만 편입하도록 상한 설정 } \\
\end{array}$ \\
\hline \multirow{3}{*}{$\begin{array}{l}\text { 투자자 } \\
\text { 보호 강화 }\end{array}$} & $\begin{array}{l}\text { 1. 파생결합증권 } \\
\text { 통합정보플랫폼 } \\
\text { 및 환매인프라 } \\
\text { 구축 }\end{array}$ & $\begin{array}{l}\text { - 외부 평가기관을 활용하여 객관적 가격산정 체계를 마련 } \\
\text { 하고 투자자가 현재가치를 확인할 수 있도록 지원 } \\
\text { - 투자자가 파생결합증권 만기 전에도 매도할 수 있는 } \\
\text { 환매 인프라 마련 }\end{array}$ \\
\hline & $\begin{array}{l}\text { 2. 투자자 위험고지 } \\
\text { 강화 }\end{array}$ & $\begin{array}{l}\text { - ‘조건 충족시 수익률’과 ‘조건 미충족시 손실률’을 } \\
\text { 균형있게 근접하여 표시 } \\
\text { - 해당내용을 읽어야 청약메뉴로 접근 허용 }\end{array}$ \\
\hline & $\begin{array}{l}\text { 3. 고위험금웅 } \\
\text { 투자자 보 } \\
\text { 의 차질없는 }\end{array}$ & $\begin{array}{l}\text { 사모행위 차단, 투자권유절차 } \\
\text { 상품 표준영업행위준칙 마련 }\end{array}$ \\
\hline
\end{tabular}

\section{5. 합리적 규제를 위한 제언}

\section{1 부적합 상품에 대한 고지, 경고 필요}

<표 12〉는 ELS, DLS의 구조적 특성을 일반적인 보험상품과 비교한 것이다. 우리나라에서 판매되는 ELS, DLS의 대다수는 스텝다운(step-down)형 구조로 발행되고 있다. ${ }^{16)}$ 구체적으로

16) 스텝다운형 ELS 상품 구조에 대한 설명은 Kwon(2019)를 참고할 것. 
한국증권학회지 제51권 1호 (2022)

살펴보면 기초자산이 일정수준 이하로 하락하지 않는다면 약속된 수익률을 지급받을 수 있는 조건이 충족되어 조기상환이 이루어지고, 조건이 충족되지 않는다면 다음 조기상환 일로 이월되며, 만기까지 조건이 충족되지 않을 경우 기초자산의 가격 하락률만큼 손실을 보는 구조이다. 이는 본질적으로 옵션 발행자가 얻는 옵션 프리미엄과 동일하다고 할 수 있으며, ELS, DLS를 매입한 금융소비자가 기초자산 가격하락 위험에 대한 보험을 상대방 (금융기관)에게 제공하는 것이다. 비유하자면 금융기관의 역할을 소비자가 수행하며, 소비자의 역할을 금융기관이 수행하는 뒤바뀐 역할극(role playing)을 하고 있는 꼴이다. ELS, DLS는 결국 낮은 확률이지만 큰 손실을 볼 수밖에 없는 초고위험 상품이며, 일반적인 상황에서 높은 확률로 작은 손실을 보면서 자신이 가진 위험을 금융기관에게 떠넘기는 소비자의 위험 감수성향과 전혀 어울리지 않는 부적합한 상품인 것이다. 금융당국에서는 이러한 본질적인 측면을 고지하고, 상품자체가 가지는 부적합성에 관하여 투자자에게 강력히 경고할 필요가 있다.

〈표 12〉보험상품과 스텝다운형 ELS, DLS 상품의 특성 비교

일반적인 보험상품과 스텝다운형 ELS, DLS 상품의 특성을 비교하였다. 금융기관은 ELS, DLS를 발행한 후 자신의 매도포지션을 자체헤지 또는 백투백헤지 함으로써 순포지션은 없는 것으로 가정한다.

\begin{tabular}{|c|c|c|c|}
\hline \multicolumn{2}{|c|}{ 구분 } & 보험상품 & ELS·DLS \\
\hline \multirow{3}{*}{$\begin{array}{l}\text { 금융 } \\
\text { 소비자 }\end{array}$} & 포지션 & - 보장매입(protection buy) & - 보장매도(protection sell) \\
\hline & & - 낮은 확률로 큰 이익(보험금 수취) & - 낮은 확률로 큰 손실(원금손실) \\
\hline & 수익 & $\begin{array}{l}\text { - 높은 확률로 작은 손실(보험료 } \\
\text { 지급) }\end{array}$ & $\begin{array}{l}\text { - 높은 확률로 작은 이익(조기/만기 } \\
\text { 상환) }\end{array}$ \\
\hline \multirow[b]{2}{*}{$\begin{array}{l}\text { 금융 } \\
\text { 기관 }\end{array}$} & 포지션 & - 보장매도(protection sell) & $\begin{array}{l}\text { - 없음 } \\
\quad \text { * 자체헤지 또는 백투백헤지 가정 }\end{array}$ \\
\hline & 수익 & $\begin{array}{l}\text { - 낮은 확률로 큰 손실(보험금 지급) } \\
\text { - 높은 확률로 작은 이익(보험료 } \\
\text { 수취) }\end{array}$ & - 일정한 이익(수수료 수취) \\
\hline
\end{tabular}

\section{2 수익률 표시 방식 개선}

<그림 4>는 2021년 4월 1일부터 6일까지 판매되었던 H증권사의 ELS상품의 투자설명서 에서 일부내용을 발췌한 것이다. 이 상품의 기초자산은 KOSPI200, S\&P500, EUROSTOXX50 지수였으며, 조기상환일은 6개월마다 도래하고, 조건 충족시(기초자산의 가격이 일정수준 이하로 하락하지 않는 경우) 년 $4 \%$ 의 수익률을 지급하는 조건이다. 이러한 자료를 통해 일반적인 수준의 금융이해력을 지닌 금융소비자들이 조건 충족시 최대수익률, 조건 미충족시 최저수익률(손실률)을 파악할 수 있지만, 기대수익률은 쉽게 파악하기 어렵다는 맹점이 있다. 발생가능한 수익률 값 ${ }^{17)}$ 과 발생빈도(가중치)를 이용하여 기대수익률을 구해 보면, $2.43 \%$ 로 도출되었다. 일선 판매현장에서 주로 강조되는 조건충족시 수익률 $4 \%$ 와는

17) 수익률 범위로 주어진 경우( $\bigcirc \%$ $\square \%)$ 중간값을 사용하였다. 
Effective Regulations to the Sale of High-risk Financial Products

큰 차이를 보임을 알 수 있다. 만약 이러한 ELS 상품이 증권사에서 소비자에게 직접 판매 되지 않고, ELF나 ELT 형태로 판매된다면 선취수수료나 신탁보수로 인해 금융소비자의 순기대수익률은 더욱 낮아지게 될 것이다. 참고로 2021년 4월 1일 현재, 저축은행의 평균 예금금리는 $1.70 \%$, 적금금리는 $2.41 \%$ 수준이다. 투자설명서 상에 기대수익률이 표시되었다 면 금융소비자는 이 상품의 기대수익률이 은행이자 수준이거나 그보다 더 낮을 가능성도 있다는 것을 쉽게 파악할 수 있었을 것이다. 복잡한 구조화상품의 투자설명서 상에 조건 충족시 수익률과 조건 미충족시 수익률만을 기재하는 관행을 개선하여, 기대수익률을 추가 적으로 기재하도록 규제할 것을 제안한다.

〈그림 4〉ELS 투자설명서의 수익률 표시 예시

2021 년 4월 1 일부터 6 일까지 청약한 H증권사의 ELS상품의 투자설명서에서 일부내용을 발췌한 것이다. 이 상품의 기초자산은 KOSPI200, S\&P500, EUROSTOXX50 지수이며, 조기상환일은 6개월마다 도래 하며, 조건충족시 수익률은 년 4\%이다. 표의 수치들은 투자시점이 1998년 1월 5일부터 2018년 3 월 28 일인 경우로 가정하여 $\mathrm{H}$ 증권사에서 자체적으로 분석한 결과이다.

\begin{tabular}{|c|c|c|c|}
\hline 상환구분 & 수익률 & 발생횟수 & 발생빈도 \\
\hline 1차 조기상환 & $2.00 \%$ & 3,746 & $77.993 \%$ \\
\hline 2차 조기상환 & $4.00 \%$ & 244 & $5.080 \%$ \\
\hline 3차 조기상환 & $6.00 \%$ & 149 & $3.102 \%$ \\
\hline 4차 조기상환 & $8.00 \%$ & 74 & $1.541 \%$ \\
\hline 5차 조기상환 & $10.00 \%$ & 53 & $1.103 \%$ \\
\hline \multirow{5}{*}{} & $12.00 \%$ & 130 & $2.707 \%$ \\
\cline { 2 - 5 } & $-80 \% \sim-70 \%$ & 0 & $0.000 \%$ \\
\cline { 2 - 5 } & $-70 \% \sim-60 \%$ & 15 & $0.312 \%$ \\
\cline { 2 - 5 } & $-60 \% \sim-50 \%$ & 132 & $2.748 \%$ \\
\cline { 2 - 5 } & $-50 \% \sim-40 \%$ & 70 & $1.457 \%$ \\
\cline { 2 - 5 } & $-40 \% \sim-30 \%$ & 160 & $3.331 \%$ \\
\cline { 2 - 5 } & $-30 \% \sim-20 \%$ & 30 & $0.625 \%$ \\
\cline { 2 - 5 } & $-20 \% \sim-10 \%$ & 0 & $0.000 \%$ \\
\cline { 2 - 5 } & $-10 \% \sim 0 \%$ & 0 & $0.000 \%$ \\
\cline { 2 - 5 } & 산기실 & 407 & $8.474 \%$ \\
\hline
\end{tabular}

<그림 5>는 구조화상품의 설명자료에서 손실 스케일을 축소하고 이익 스케일을 과장한 수익구조 그래프를 스케일 왜곡없는 그래프로 변환해본 예시이다. Panel A는 금융감독원의 2019년 12월 5일자 보도자료(제목: 금융분쟁조정위원회, DLF 투자손실 40\% 80\% 배상 결정 ${ }^{18)}$ 에서 발췌한 것이다. 이 상품의 기초자산은 영국 CMS 7년 금리, 미국 CMS 5년 금리이고, 조기상환일은 3 개월마다 도래하며, 조건충족시 수익률은 $3.3 \%$ 이다. Panel B는 <그림 4>에서 제시된 상품과 동일한 상품이다. Panel A와 Panel B에서 왼쪽 그림들을 살펴

18) Financial Supervisory Service(2019a) 
보면 손실 스케일에 비해서 이익 스케일이 10 배가량 과장되어서 그래프로 표현되고 있음을 알 수 있고, 이러한 스케일 왜곡을 제거하고 오른쪽 그림들로 변환하면 소탐대실형의 초고 위험상품임이 그래프상에 뚜렷하게 드러남을 알 수 있다. 스케일 왜곡이 없는 그래프는 금융소비자들이 상품의 위험성을 정확하게 인지하는데 있어 큰 도움이 될 것으로 기대된다. 금융당국에서는 수익률을 글씨로 표시하는 것에만 규제를 도입하여 조건충족시 수익률, 미충족시 수익률을 글씨크기 등에서 균형있게 표시하도록 하였으나, 이에 더해 그래프로 표시하는 경우에도 이익을 과장하고 손실을 축소하여 표시하지 못하도록 강제할 필요가 있다.

\section{〈그림 5〉 왜곡된 수익구조 그래프}

손실 스케일을 축소하고 이익 스케일을 과장한 수익구조 그래프에 대하여 스케일을 왜곡하지 않고 표시해 본 예시이다. Panel A는 금융감독원의 2019년 12월 5일자 보도자료(금융분쟁조정위원회, DLF 투자손실 40\% $80 \%$ 배상 결정)에서 발췌한 것이다. 이 상품의 기초자산은 영국 CMS 7년 금리, 미국 CMS 5년 금리이며, 조기상환일은 3개월마다 도래하며, 조건충족시 수익률은 $3.3 \%$ 이다. Panel $\mathrm{B}$ 는 2021년 4월 1 일부터 6일까지 청약한 H증권사의 ELS상품의 투자설명서 발췌한 것이다. 이 상품의 기초자산은 KOSPI200, S\&P500, EUROSTOXX50 지수이며, 조기상환일은 6개월마다 도래하며, 조건 충족시 수익률은 년 $4 \%$ 이다.

Panel A: CMS 금리 연계 사모펀드 예시
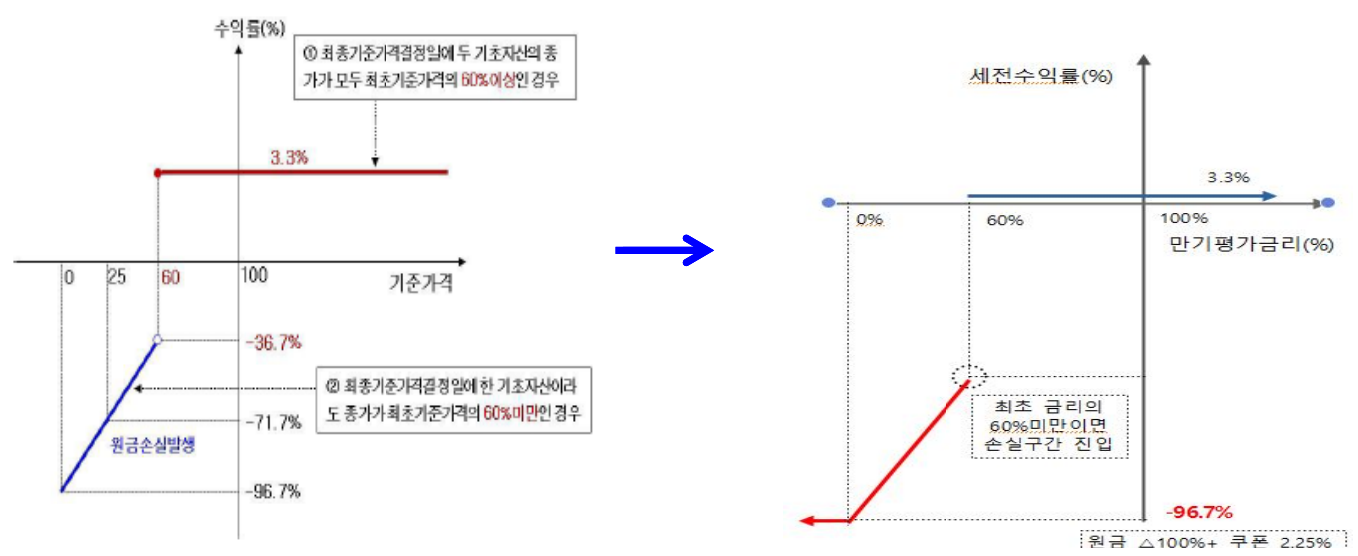

Panel B: ELS 상품 예시
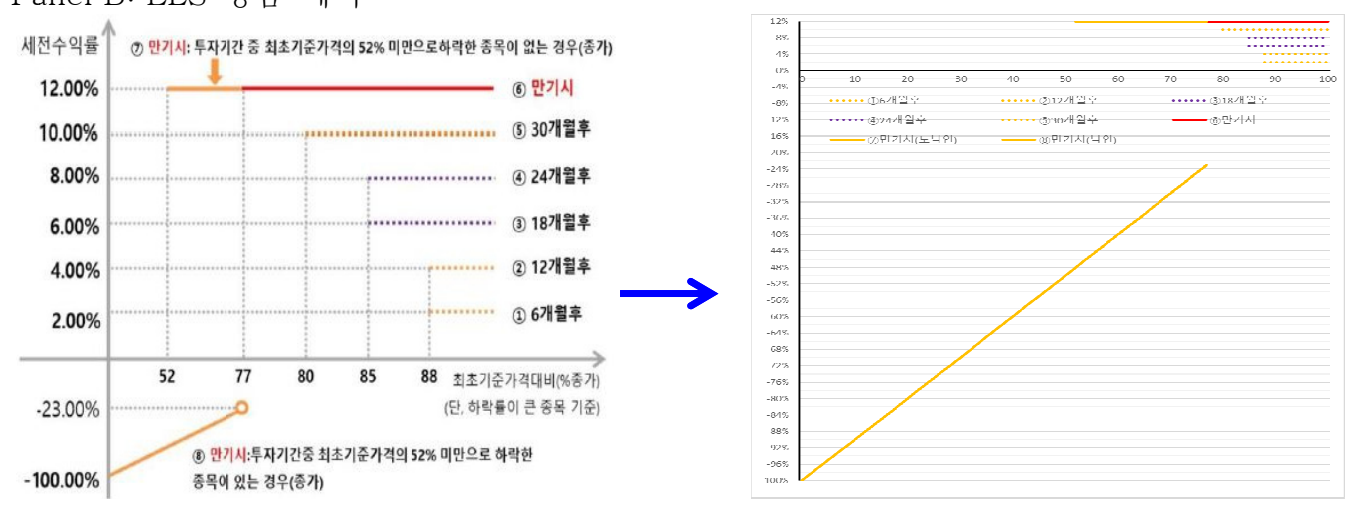
Effective Regulations to the Sale of High-risk Financial Products

\section{3 판매업무와 투자자성향 파악 업무 분리}

금융감독원의 2019년 10월 2일자 보도자료(제목: 주요 해외금리 연계 DLF 관련 중간 검사결과 ${ }^{19)}$ 의 DLF 분쟁조정 신청 주요사례를 살펴보면 다음과 같다. 첫 번째 사례는 은행 직원이 고객의 투자자 성향을 임의로 작성했던 사건이다. 은행직원이 고객에게 전화통화로 “안전하고 조건 좋은 상품이 나왔으니 빨리 가입해야 한다”라며 1 분 동안 DLF를 권유 하였는데, 고객은 예금을 권유하는 것으로 믿고 가입하게 되었다. 은행직원은 고객의 직장을 방문하여 거래신청서를 작성하였고, 투자자정보확인서는 고객의 투자성향이 “공격투자형” 으로 분류되어 위험등급 1 등급인 DLF에 가입할 수 있도록 은행직원이 임의작성하여 계약을 체결하게 되었다. 두 번째 사례는 은행직원이 DLF, ELF를 알지 못하고 거래경험이 없는 75세 고령 고객의 투자자 정보를 확인하는 과정에서 3년간의 거래경험이 있는 것으로 사실과 다르게 임의로 체크하였음에도 불구하고 고객의 등급이 공격투자형( 1,2 등급 상품 투자가능)이 아닌 적극투자형(3등급 상품 투자가능)으로 분류되자, 투자자 성향 등급보다 위험도가 높은 $\mathrm{DLF}$ 를 판매하기 위해 부적합 금융상품 선택 확인서를 작성하도록 한 사건이다. 이상의 주요사례를 보면 판매실적을 위해 고객의 투자자성향을 조작하거나 무리하게 조정하여 고위험 금융투자상품을 판매하고자 하는 유인이 존재함을 알 수 있다. 이러한 문제점을 해결하기 위해 금융당국에서는 $\mathrm{KPI}$ 구성요소에 고객수익률 비중을 확대하고, $\mathrm{KPI}$ 적정성을 감독하겠다는 대책을 내 놓았으나, 판매직원들이 투자자성향 파악 업무를 동시에 수행하는 이상, 투자자 성향 등급을 끌어올리려는 유인 자체를 차단하는 것은 어려워 보인다.

근본적인 대책으로서 금융투자상품 판매업무와 투자자성향 파악 업무를 분리하는 방안을 제안한다. 예를 들면, 은행에서 개인대출 업무는 신용등급 산출 업무와 분리되어 있기 때문에 은행직원이 대출실적을 위해 고객의 신용등급을 끌어올리는 것이 불가능하다. 이와 유사 하게 고위험 금융투자상품 판매업무에 있어 본점의 특정부서에서 고객의 투자자성향 등급을 산정하도록 하고, 지점의 판매직원들은 해당 등급에 부합하는 상품을 판매하는 업무에만 전념하도록 한다면 불완전판매를 크게 감소시킬 수 있을 것으로 판단된다.

\section{4 시나리오 테스트 및 결과 표시 방식 개선}

<그림 6>은 금융감독원의 2019년 10월 2일자 보도자료(제목: 주요 해외금리 연계 $\mathrm{DLF}$ 관련 중간 검사결과 $)^{20)}$ 에서 발췌한 것으로 국내 시중은행 한 곳의 사내 상품게시판에 공개된 자료이다. 금융상품의 테스트는 과거데이터에 기반한 백테스트 방식으로 이루어지고 있으며, 만기상환 가능성이 $100 \%$, 원금손실 가능성 0\%라는 낙관적 전망치를 강조하고 있음을 알 수 있다. 흥미로운 점은 원금손실가능성이 $0 \%$ 임에도 불구하고 어떻게 고객

19) Financial Supervisory Service(2019b).

20) Financial Supervisory Service(2019b). 
한국증권학회지 제51권 1호 (2022)

수익률은 은행이자율의 2 배 가량인 $4.2 \%$ 가 달성될 수 있는가 하는 점이다. 원금손실 가능성이 전혀 없는 상품의 기대수익률은 무위험이자율이라는 재무학 상식을 고려하면 <그림 6>은 모순적인 내용을 담고 있는 것이다. 금융상품의 테스트는 편리성이나 객관성 확보 등을 위해 과거데이터를 이용하면서, 가격책정(pricing)은 필연적으로 시장원리에 따라 앞으로 예상되는(forward looking) 정보를 반영하기 때문에 발생하는 문제라고 할 수 있다. 우리나라에서 금융상품 불완전 판매의 원조 격이라고 할 수 있는 '우리파워인컴펀드'의 사례에서도 백테스트 결과를 이용하여 $100 \%$ 안전하다는 점을 강조했던 2005년의 펀드 제안서가 비판을 받았었다. 14년이 경과한 2019년에 작성된 DLF 상품 설명자료가 이러한 모순적인 관행을 답습하고 있다는 것은 안타까운 현실이다.

금융투자업계에서 유명한 경고문구인 '과거의 성과가 미래 성과를 보장하지 않는다'에서 알 수 있듯이 백테스트 결과는 지나간 과거에 대한 분석일 뿐 미래에 반복되지 않을 것은 자명하다. '고난도 금융투자상품 제조 및 판매에 관한 표준영업행위준칙' 중 금융투자상품 테스트에 관한 내용에서는 다양한 부정적인 시장상황 하에서 시나리오 분석을 하라고 규제 하고 있지만, 금융회사에서는 지금까지 해오던 관행대로 장기간의 과거데이터를 다양한 부정적인 시장상황이라고 주장하면서 백테스트 결과에 경고문구를 삽입하는 수준에서 설명 자료를 만들 가능성이 높다고 판단된다. 금융투자상품을 테스트하는 관점에 전환이 필요 하며, 백테스트에 더해 미래예상(forward looking) 테스트를 추가할 것을 제안한다. 또한 다양한 시나리오에 대한 기준도 모호한 측면이 있기 때문에 구체적인 기준을 마련할 필요가 있다. 예를 들면, 5 개 $(20 \%, 40 \%, 60 \%, 80 \%, 100 \%)$ 의 원금 손실률에 대한 미래 시나리오를 제시하도록 하는 방안을 고려해 볼 수 있겠다.

〈그림 6〉금융투자상품 테스트 예시

금융감독원의 2019년 10월 2일자 보도자료(제목: 주요 해외금리 연계 DLF 관련 중간 검사결과)에 발췌한 것으로 국내 시중은행 한 곳의 사내 상품게시판에 공개된 자료이다.

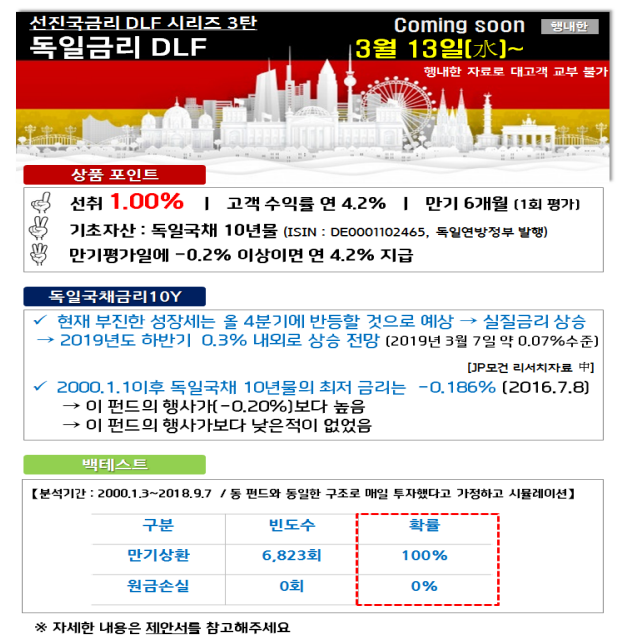


Effective Regulations to the Sale of High-risk Financial Products

\section{5 금융소비자 착취상품 선별 및 퇴출}

고위험상품의 복잡성이 금융소비자를 착취하기 위한 전략이 아니라 금융혁신의 결과라면, 그 복잡성이 가져오는 이익의 상당부분이 궁극적으로 금융소비자에게 돌아가야 할 것이다. DLF 상품의 제조 및 판매와 관련된 생태계에서 누가 이익을 취하는지 조사한 Financial Supervisory Service(2019b)의 내용을 살펴보도록 하자. 상품설계 및 헤지를 담당하는 외국계 $\mathrm{IB}$ 는 $3.43 \%$, 펀드판매를 담당하는 은행은 $1 \%$, DLF가 편입하게 될 DLS를 발행하는 국내 증권사는 $0.39 \%$, 펀드운용을 담당하는 자산운용사는 $0.11 \%$ 수준의 수수료 수익을 거두어 들였는데 합산하면 무려 $4.93 \%$ 이며, 이는 6 개월을 기준으로 계산된 것이다. 이에 반해 금융소비자에게 돌아가는 수익은 조건충족시 최대수익률 $2.02 \%$ 수준이며, 은행의 선취 판매수수료 $1 \%$ 를 차감하면 $1.02 \%$ 에 불과하다. 1 년 기준으로 환산하면 금융회사는 $9.86 \%$, 금융소비자는 $2.04 \%$ 이다. 여기서, $9.86 \%$ 는 위험이 거의 없는 확실한 수익률이며, $2.04 \%$ 는 최상의 시나리오에서 도출되는 최대수익률이라는 점 또한 감안해야 한다. 이러한 결과는 2019년 10월 2일에 발표되었는데, 해당시점에 저축은행 평균 예금금리는 $2.44 \%$ 에 달하고 있다. DLF 상품은 소비자에게 제공하는 이익이 전혀 없는 착취상품이라는 점을 지지해주고 있다. 앞서 살펴본 <그림 4 >에서 기대수익률이 $2.43 \%$ 인 ELS 상품도 착취상품에 해당할 가능성이 높다. ELS를 기반으로 은행에서 신탁형태로 판매하는 ELT 상품의 경우 0.6 0.8\% 수준의 신탁보수를 선취하는데, 신탁보수를 차감하면 기대수익률이 저축은행 예적금 이자율과 비슷하거나 오히려 낮아지게 된다. Henderson and Pearson(2011)도 유사한 실증분석 결과를 제시한다. 이들은 SPARQS(Stock Participation Accreting Redemption Quarterly-pay Securities)라는 구조화 상품에 대해 분석하였는데, 그 기대수익률이 무위험 수익률보다 작다고 판단하였다. 보통수준의 금융이해력을 지닌 금융소비자가 복잡한 금융 상품의 기대수익률을 추정하기란 매우 어려운 일이며, <그림 3>에서 살펴보았듯이 시장경쟁에 의해서도 착취상품은 사라지지 않을 가능성이 크기 때문에 금융당국에서 이러한 착취상품을 선별하고 퇴출시키는 방안을 강구해야 할 것이다.

\section{6 과도한 보수 및 수수료 규제}

Fama and French(2009)는 균형회계(equilibrium accounting)라는 관점을 제시하며, 액티브 투자는 비용차감 전 기준으로 제로섬(zero-sum) 게임이며, 비용차감 후 기준으로 네거티브섬 (negative-sum) 게임이라는 점을 설명하고 있다. 이러한 관점은 Sharpe(1991), Bogle(2007) 에서도 동일하게 제시되고 있으며, 보글(Bogle)이 설립한 자산운용사 뱅가드의 투자철학 으로 강조되고 있다. 앞서 제4장에서 살펴본 금융당국의 고위험 금융상품 관련 제도 개선 방안들은 금융소비자 보호를 위해 금융회사의 책임과 역할을 강조하고 있으며, 전반적으로 업무부담을 높이기 때문에 금융회사의 비용 증가로 이어지게 될 것이다. 또한, 금융회사는 이러한 비용을 금융소비자에게 전가하기 위해서 평균적인 보수 및 수수료를 증가시킬 소지가 
한국증권학회지 제51권 1호 (2022)

있다. 그렇게 된다면 금융소비자를 위한 규제의 효과는 상당부분 퇴색할 것이므로, 보수 및 수수료에 대한 합리적 규제안이 필요하다. 최소한의 기준으로서 금융투자상품의 기대 수익률에서 연율화된 보수와 수수료를 차감한 값이 은행의 예적금 이자율보다는 높아야 한다는 부등식 규제 방안을 제안한다.

\section{7 투자자정보 파악 및 투자자성향 분류방법 개선}

금융투자협회 표준투자권유준칙 여덟 번째 항목인 ‘투자자정보 파악 및 투자자성향 분석 등'에 따르면 금융회사의 임직원은 투자자정보를 파악하고 이에 따라 분류된 투자자의 성향을 투자자에게 제공하여야 한다. 특히, 금융소비자보호법 제 17 조 2 항 2 호에 의거 3 개 항목 (금융상품 취득 또는 처분 목적, 재산상황, 취득 또는 처분 경험)은 반드시 필요한 정보이다. 금융회사는 이러한 투자자정보 각 항목에 대하여 답변을 점수화(scoring)하여 투자자성향을 자체적인 기준으로 분류하게 된다. 투자자성향을 특정 유형으로 지칭할 때 유형 개수, 명칭 등에도 자율성이 부여된다. 예를 들면, <그림 1 >과 같이 공격투자형, 적극투자형, 위험중립형, 안정추구형, 안정형으로 구분하는 5 단계 유형분류가 업계에서 대체로 선호되는 편이다.

<그림 7>은 D증권사의 HTS 프로그램의 투자자정보관리 화면에서 발췌한 투자자성향 분류를 위한 투자자정보 확인 항목 예시이다. 총 11 개의 항목에 대하여 투자자 정보를 파악 하고 있으며, 이중 연령은 실명의 계좌정보를 통해 자동으로 표시되고, 나머지 항목들은 모두 고객의 주관적 자기선언에 의해 스코어링 되고 있다. 여기서 지적되는 가장 큰 문제는 객관성의 결여인데 고객이 원한다면 누구나 최고점수를 받을 수 있고 공격투자성향으로 분류될 수 있다는 점이다. 물론 투자목적, 위험감수, 투자의향 등은 주관적 응답으로 측정될 수밖에 없는 항목이지만, 투자지식, 투자경험, 소득 등은 충분히 객관적으로 측정될 수 있는 항목들이므로 실제 데이터에 기반하여 측정되는 것이 바람직하다. 예를 들면, 금융투자와 관련한 기초지식(화폐의 시간가치, 복리효과, 분산투자효과, 위험과 수익률의 상충관계 등)을 간단한 퀴즈를 통해 측정하는 방안, 금융기관과의 과거 거래내역 데이터를 통해 특정상품에 대한 투자경험을 확인하는 방안, 비대면 대출업무 등에서 활발히 활용되고 있는 국세청 자료 스크래핑 기법을 통해 소득현황을 확보하는 방안을 고려해 볼 수 있을 것이다.

또한 투자자정보를 파악하여 투자자성향을 분류한 후 투자권유에 활용하는 궁극적인 이유는 적합한 상품을 자기책임원칙 하에 최종 선택할 수 있도록 유도하고 불완전판매를 방지하기 위함이라고 할 수 있다. 그러나 대부분의 항목에 동일한 가중치가 부여됨으로써 어떠한 항목이 자기책임과 관련되는지 불명확하다는 점이 문제로 지적된다. Kwon and Ban(2021)은 한국금융투자자보호재단의 설문조사 ${ }^{21)}$ 원자료를 이용하여 금융소비자의 자기책임인식 ${ }^{22}$ 과

21) 설문조사의 개요 및 결과에 대해서는 Korea Financial Investors Protection Foundation(2019)를 참조할 것.

22) 판매직원이 펀드투자를 권유했을 때, 투자자 본인과 판매직원 사이의 책임 비중이 어떠한지를 질문함으로써 투자자 자기책임인식이 강한 응답자와 약한 응답자를 구분할 수 있다. 
Effective Regulations to the Sale of High-risk Financial Products

관련되는 요인을 분석하였다. 연구결과에 따르면 금융지식이 많을수록, 나이가 많을수록, 학력이 높을수록 자기책임 인식이 유의하게 증가하며 소득과 자산의 영향력은 유의하지 않은 것으로 나타났다. 금융투자업계에서 투자자정보를 파악하는 문항을 설계하고 투자자 성향을 분류하기 위한 스코어링 가중치를 산정하는데 있어 이러한 학계의 연구결과들을 반영할 필요가 있다고 판단된다.

〈그림 7〉 투자자성향 분류를 위한 투자자정보 확인 항목

$\mathrm{D}$ 증권사의 HTS 프로그램의 투자자정보관리 화면을 발췌한 것이다. 총 11 개의 항목의 투자자 정보를 파악하고 있으며, 자동으로 선택되는 고객연령 항목을 제외하고 모든 항목은 응답자의 주관적 자기 선언에 의해 점수가 매겨진다.

\begin{tabular}{|c|c|c|}
\hline \multicolumn{2}{|r|}{ 개인고격 투자자정보 확인 항목 } & 배점 \\
\hline 고객연령 & 60세 64 세 $\bigcirc$ 65세 69 세 $\bigcirc$ 70세 79 세 & 5 \\
\hline 투자경험기간 & ○년이상 $\bigcirc$ 2년이상 3 년이내 $\bigcirc$ 1년이상 2년이내 $\bigcirc$ 개월이상 1 년이내 $\bigcirc 6$ 개월이내 $\bigcirc$ 투자경험없음 & 5 \\
\hline 투자경험 (중복가능) & $\begin{array}{l}\square \text { 해외주식, 해외펀드, 파생상품펀드, 주식 신용거래, 선물, 옵션 등 파생상품 } \\
\square \text { 주식, 주식형 펀드, ELS/DLS } \\
\square \text { 회사채, 혼합형 편드 } \\
\square \text { 특수채, 금융채, 채권형편드, 원금보장형ELS, 외화RP } \\
\square \text { 국. 공채, MMMF, CMA, RP } \\
\square \text { 투자경험 없음 }\end{array}$ & 5 \\
\hline 파생결합상품 투자경험 & ○ 투자경험 있음 투자경험 없음 & \\
\hline 투자지식 & 보톻 $\bigcirc$ 낮음 $\bigcirc$ 매우 낮음 $\bigcirc$ 전혀 없음 & 5 \\
\hline 소득현황 & $\begin{array}{l}\text { (억원 미상 } \quad 5,000 \text { 만원 미상 } 1 \text { 억원 미만 } \quad 3,600 \text { 만원 이상 } 5,000 \text { 만원 미만 } \\
01,200 \text { 만원 미상 } 3,600 \text { 만원 미만 } \quad 01,200 \text { 만원 미만 } \quad \text { 소득 없음 }\end{array}$ & 5 \\
\hline 재산상태 & $\begin{array}{l}\text { 일정한 수입이 있으며, 현 수준을 유지하거나 증가할 것으로 예상 } \\
\text { 일정한 수입미 있으나, 감소할 가능성미 높음 } \\
\text { 수입은 있으나 불안정함 } \\
\text { 연금외 소득없음 }\end{array}$ & 5 \\
\hline 투자자금비중/금융자산 & ○ 30\%이상 $\quad 20 \%$ 미상 30\%미만 $\quad 10 \%$ 이상 20\%미만 $\quad 5 \%$ 이상 10\%미만 & 5 \\
\hline 투자목적 & 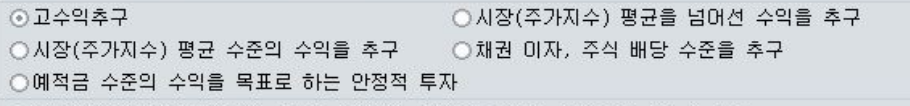 & 5 \\
\hline 위험감수 & $\begin{array}{l}\text { 기대수익미 높다면 위험이 높아도 감수할 수 있음 } \bigcirc \text { 일부 손실은 감수할 수 있음 } \\
\text { 최소한의 손실만 감수 } \quad \text { 무조건 원금 보전 }\end{array}$ & 5 \\
\hline 투자의향(중복가능) & $\begin{array}{l}\square \text { 해외투자 상품, 파생상품, 사모펀드, 해외 부동산 펀드 } \\
\square \text { 주식형 상품, ELS/DLS } \\
\square \text { 회사채, 혼합형 펀드, 국내부동산 펀드 } \\
\square \text { 외화RP, 원금보장형 } \mathrm{ELB} / \mathrm{DLB} \\
\square \text { 국공채, MMF, CMA, RP 등 원금보존상품 } \\
\square \text { 정기예금 신탁 }\end{array}$ & 5 \\
\hline
\end{tabular}

\section{8 시장규율, 금융감독, 사법제도 간의 조화로운 역할분담}

사모펀드는 공모펀드와 비교하여 판매, 운용, 각종 정보 제공 의무, 금융감독 등의 측면 에서 자유로워 과감한 자산운용을 통해 고수익을 추구하는 모험자본으로서 자본시장의 역 동성을 제고하는 것이 그 도입 취지라고 할 수 있다. 사모펀드 불완전판매 문제가 불거진 이후로 <표 10〉에서 살펴본 바와 같이 많은 규제가 새롭게 도입되었고 상당부분은 공모 펀드 규제를 그대로 차용하게 되었다. 이로 인해 업계에서는 사모펀드의 취지가 훼손될 수 있다는 우려도 나타나고 있다. 
한국증권학회지 제51권 1호 (2022)

감독과 규제에 앞서 사모펀드 판매사와 운용사가 책임있는 역할수행을 할 수 있는 합리 적인 시장규율을 통해 사모펀드와 관련된 건전한 생태계와 투자환경이 정착되어야 할 것 이다. 감독당국에서는 사모펀드 운용사가 손해배상 재원을 공모펀드와 동일한 수준으로 수탁고의 $0.03 \%$ 를 적립토록 하였으나, 시장규율 측면에서 보완이 필요하다. 공모 운용사 에서는 리스크 풀링(pooling)으로 인해 운용중인 다수의 펀드 중에서 일부의 펀드에서만 사고가 발생하는 효과가 기대되는 반면, 사모 운용사는 소수의 펀드에 집중하므로 이러한 효과를 기대하기 어렵고 펀드 자체의 위험도 높아 사고발생 확률도 크기 때문이다. 따라서 동일한 요율을 적용하기 보다는 펀드의 위험, 운용사의 수탁고와 부담능력(운용보수율)에 따라 요율을 차등적으로 적용할 것을 제안한다. ${ }^{23)}$ 또한 감독당국에서는 사모펀드 판매전과 판매 후 판매사의 책임을 대폭 강화하였으나, 판매사의 도덕적 해이를 막고 책임있는 역할 수행을 강제할 만한 유인체계가 부족한 실정이다. 판매사가 운용사의 위법행위, 불건전 운용행위 등에 대한 1차적인 스크리닝과 모니터링을 할 수 있는 유인체계로서 판매사가 특정 사모펀드를 판매하여 얻는 판매보수와 판매수수료 범위 내에서 해당 사모펀드에 대해 매칭 투자하도록 하는 방안을 제안한다. ${ }^{24)}$

한편, 라임펀드 및 옵티머스펀드와 같은 일부 사모펀드 문제로 인하여 사모펀드 본연의 순기능이 훼손되는 지나친 규제를 지양해야 할 것이다. 옵티머스펀드는 운용사가 펀드를 설계하는 시점부터 사기행각(시장에 존재하지 않는 정부 산하기관 및 공공기관 매출채권에 투자하겠다는 제안서)을 통해 판매사와 투자자를 속였다는 사실이 드러났으며, 라임펀드는 주가조작 세력과 결탁하여 사모펀드 자금으로 특정기업 전환사채를 매입한 후 주가조작 범죄를 시도하다가 실패하였음이 밝혀졌다. ${ }^{25)}$ 이러한 문제들은 사모펀드 자체의 문제라기 보다는 금융범죄의 문제라고 할 수 있다. 범죄와 처벌의 경제학(economics of crime and punishment)이라는 분야를 개척한 Becker(1968)에 따르면 범죄의 기대편익이 범죄의 기 대비용보다 클수록 범죄의 발생 가능성 역시 증가한다. 여기서 기대비용은 적발될 확률과 처벌강도에 의해 결정된다. 따라서, 사법체계 내에서 금융범죄의 적발가능성을 높이고, 벌금 및 형량을 높이는 방안도 함께 추진될 필요가 있다.

\section{6. 결론}

2019년과 2020년 언론을 뜨겁게 달궜던 DLF 사태, 라임·옵티머스 사모펀드 사태는 광 범위한 금융소비자 피해를 양산하면서, 금융회사의 부도덕한 운용행태 및 판매행태 문제를

23)은행권에서 2014년부터 적용되고 있는 차등예금보험료율 제도를 참고할 만하다. 예를 들면, 보험료율이 시중은행은 예금평잔의 $0.08 \%$, 저축은행은 시중은행보다 5 배가 높은 $0.4 \%$ 이다.

24)주식시장에서 기업의 IPO 시점에 상장주관사가 해당기업 주식을 일정량 인수하는 의무인수제도를 참고할 만하다.

25)KBS에서 방영된 2021년 2월 7일자 ‘시사기획 창: 라임\&주가조작단’을 참고하였다. 
Effective Regulations to the Sale of High-risk Financial Products

부각시켰으며, 고위험 금융상품에 대한 경각심을 유발하고, 금융소비자 보호의 필요성을 우리 사회에 각인시키는 계기가 되었다.

우리나라에서 2021년 3월 말 기준으로 복잡한 구조화상품의 대표격인 ELS 및 DLS 시장은 미상환잔고 기준으로 82조 원 규모를 형성하고 있으며, 이는 주식형 펀드시장과 맞먹는 규모 이다. ELS는 공모형태, DLS는 사모형태로 주로 판매되고 있으며, ELS, DLS를 특정금전신탁 형태로 판매하는 $\mathrm{ELT}, \mathrm{DLT}$ 상품은 주로 은행에서 판매되는 경향이 있다. 펀드시장은 순자산 기준으로 공모 302조 원, 사모 453조 원 규모의 시장을 형성하고 있으며, 이중에서 고위험 상품으로 분류되는 범주인 파생형 펀드는 공모 25.4 조 원, 사모 23.6 조 원 규모를 나타내고 있다.

금융당국에서는 DLF 사태, 라임·옵티머스 사태 후 '고위험 금융상품 투자자 보호 강화를 위한 종합 개선방안', '고난도 금융투자상품 제조 및 판매에 관한 표준영업행위준칙', '사모 펀드 현황 평가 및 제도개선 방안' '파생결합증권시장 건전화 방안’ 등 다양한 개선책들을 내놓았다.

본 연구는 이러한 규제방안에도 불구하고 여전히 미흡한 점을 논의하고 합리적 규제를 위한 제언을 다음과 같이 여덟 가지로 나누어 제시하였다. 첫째, 대다수의 ELS, DLS 상품은 금융소비자가 기초자산 가격하락 위험에 대한 보험을 금융기관에게 제공하는 구조로 소비자의 일반적인 위험감수성향과 어울리지 않는 부적합 상품이다. 이러한 본질적인 측면을 고지하고 경고할 필요가 있다. 둘째, 구조화상품의 투자설명서상에서 기대수익률을 알기 어렵고, 손실 스케일을 축소하고 이익 스케일을 과장하는 수익구조 그래프가 만연해 있다. 기대수익률을 표시하도록 하고, 그래프를 왜곡하지 못하도록 규제해야 한다. 셋째, 판매사의 직원이 판매 업무와 투자자성향 파악 업무를 동시에 수행하는 현 상황에서 투자자성향을 조작하거나 등급을 무리하게 조정하려는 유인이 존재한다. 두 업무를 분리시켜 특정부서에서 투자자 성향 등급을 산정하게 하고, 판매직원들은 등급에 부합하는 상품 판매 업무에만 전념한다면 불완전판매를 감소시킬 수 있을 것이다. 넷째, 대부분의 시나리오 테스트가 과거 데이터에 기반한 백테스트 결과를 표시함으로써 $100 \%$ 안전하다는 점만 강조하고 있으나, 과거의 성과는 미래에 반복되지 않는 것이 일반적이다. 관점을 미래예상(forward looking) 테스트로 전환해야 하며, 다양한 시나리오에 대한 구체적인 기준을 마련할 필요가 있다. 다섯째, 복잡한 상품에 투자한 금융소비자의 기대수익률이 은행의 예적금 금리에도 미치지 못하는 착취상품이 존재한다. 금융당국에서는 착취상품을 선별하고 퇴출시키는 방안을 강구해야 한다. 여섯째, 금융당국의 여러 가지 제도개선 방안들이 금융회사의 책임과 역할을 강조하게 되면서 업무 부담 증대로 인해 평균적인 보수 및 수수료 수준이 증가할 소지가 있다. 보수 및 수수료에 대한 합리적 규제안이 필요하다. 일곱째, 투자자정보를 파악하는 문항이 고객의 자기선언에 의해 점수가 매겨지므로 객관성이 결여되고, 가중치 또한 자기책임원칙과 무관하게 기계 적으로 설정되는 문제가 있다. 투자지식, 투자경험, 소득 등은 실제데이터에 기반하여 측정 되는 것이 바람직하고, 자기책임 인식과의 관련성을 토대로 점수 가중치를 선정할 필요가 
한국증권학회지 제51권 1호 (2022)

있다. 여덟째, 공모펀드 규제의 상당부분이 사모펀드시장에서 차용되므로 과감한 자산운용을 통해 고수익을 추구하는 모험자본 취지가 훼손될 우려가 있다. 감독과 규제에 앞서 사모 펀드 운용사 및 판매사가 책임있는 역할을 수행하도록 하는 합리적인 시장규율이 필요하며, 금융범죄의 적발가능성과 처벌을 강화하는 방안도 함께 추진될 필요가 있다.

금융기관이 고위험 금융상품의 제조와 판매에 있어 금융소비자 보호를 위해 책임있는 역할을 수행하면서, 지속적인 혁신을 통해 기존의 상품으로는 달성 불가능한 투자기회와 수익구조를 제공하게 된다면, 금융소비자로부터 신뢰를 회복할 수 있을 것이다. 고위험 금융상품이 금융이해력이 부족한 금융소비자를 착취하는 수단이 아니라, 효율적인 자본중개와 위험분산 기능을 수행하며 자본시장의 역동성을 제고하는 수단이 되기를 기대한다. 
Effective Regulations to the Sale of High-risk Financial Products

\section{References}

Becker, G. S., 1968, Crime and Punishment: An Economic Approach, Journal of Political Economy, Vol. 76, pp. 169-217.

Bogle, J. C., The Little Book of Common Sense Investing, John Wiley \& Sons, New Jersey, 2007.

Carlin, B. I., 2009, Strategic Price Complexity in Retail Financial Markets, Journal of Financial Economics, Vol. 91, pp. 278-287.

Fama, E. F., and K. R. French, Why Active Investing is a Negative Sum Game, Fama/French Forum Essays, 2009, https://famafrench.dimensional.com/essays/why-active-investi ng-is-a-negative-sum-game.aspx.

Financial Industry Regulatory Authority, Heightened supervision of complex products, Regulatory Notice 12-03, 2012, https://www.finra.org/rules-guidance/notices/12-03.

Financial Services Commission and Financial Supervisory Service, Comprehensive improvement plan to strengthen the protection of investors in high-risk financial products, 2019, https://www.fsc.go.kr/no010101/74020.

Financial Services Commission and Financial Supervisory Service, Evaluation of the Status of Private Placement Funds and Plan to Improve the System(final draft), 2020, https://www.fsc.go.kr/no010101/74294.

Financial Services Commission, Financial Supervisory Service, Korea Exchange, and Korea Financial Investment Association, Derivative embedded securities market consolidation plan, 2020, https://www.fsc.go.kr/no010101/74474.

Financial Supervisory Service, Financial dispute mediation committee's decision to compensate $40 \%$ to $80 \%$ of DLF investment loss, Press Release, 2019a, https://www.fss. or.kr/fss/kr/promo/bodobbs_view.jsp?seqno=22742.

Financial Supervisory Service, Interim inspection results and future countermeasures for Lime Asset Management, Press Release, 2020a, https://www.fss.or.kr/fss/kr/promo/ bodobbs_view.jsp?seqno=22912.

Financial Supervisory Service, Interim inspection results and future countermeasures for Optimus Asset Management, Press Release, 2020b, https://www.fss.or.kr/fss/kr/prom o/bodobbs_view.jsp?seqno=23266.

Financial Supervisory Service, Interim inspection results for DLF linked to major overseas interest rates, Press Release, 2019b, https://www.fss.or.kr/fss/kr/promo/bodobbs_vie w.jsp?seqno=22603. 
한국증권학회지 제51권 1호 (2022)

Gabaix, X., and D. Laibson, 2006, Shrouded Attributes, Consumer Myopia, and Information Suppression in Competitive Markets, Quarterly Journal of Economics, Vol. 121, pp. 505-540.

Ghent, A. C., W. N. Torous, and R. I. Valkanov, 2017, Complexity in structured finance, $R e^{-}$ view of Economic Studies, Vol. 86, pp. 694-722.

Henderson, B. J., and N. D. Pearson, 2011, The Dark Side of Financial Innovation: A Case Study of the Pricing of a Retail Financial Product, Journal of Financial Economics, Vol. 100, pp. 227-247.

Koh, B. S. K., F. Koh, D. L. K. Chuen, L. K. Guan, D. Ng, and P. K. Fai, 2015, A risk- and complexity-rating framework for investment products, Financial Analysts Journal, Vol. 71, pp. 10-28.

Korea Financial Investment Association, Standard business conduct rules for manufacturing and sales of complex financial investment products, 2020, https://law.kofia.or.kr/serv ice/law/lawPartCurrentList.do?seq=3\&root=0.

Korea Financial Investors Protection Foundation, 2018 Fund Investors Survey Results, Gwang-mun-dang, Seoul, 2019.

Kwon, S., 2019, The Evolution of Complexity of the ELS and the Financial Consumer Protection in Korea, Journal of Korean Economic Development, Vol. 25, pp. 75-103.

Kwon, S., and J. Ban, 2021, Effects of Financial Knowledge on Financial Behaviors, Korean Journal of Financial Management, forthcoming.

Ross, S. A., 1976, Options and Efficiency, Quarterly Journal of Economics, Vol. 90, pp. 7589.

Sharpe, W. F., 1991, The arithmetic of active management, Financial Analysts Journal, Vol. 47, pp. 7-9. 